Article

\title{
Modelling Hydrological Processes and Identifying Soil Erosion Sources in a Tropical Catchment of the Great Barrier Reef Using SWAT
}

\author{
Vahid Rafiei ${ }^{1, *(D)}$, Afshin Ghahramani ${ }^{2}$, Duc-Anh An-Vo ${ }^{1}$ and Shahbaz Mushtaq ${ }^{1}$ \\ 1 Centre for Applied Climate Sciences, Institute for Life Sciences and the Environment, \\ University of Southern Queensland, Toowoomba 4350, Australia; Duc-Anh.An-Vo@usq.edu.au (D.-A.A.-V.); \\ Shahbaz.Mushtaq@usq.edu.au (S.M.) \\ 2 Centre for Sustainable Agricultural Systems, Institute for Life Sciences and the Environment, \\ University of Southern Queensland, Toowoomba 4350, Australia; Afshin.Ghahramani@usq.edu.au \\ * Correspondence: Vahid.rafiei@usq.edu.au
}

Received: 18 June 2020; Accepted: 30 July 2020; Published: 2 August 2020

\begin{abstract}
Study region: North Johnstone catchment, located in the north east of Australia. The catchment has wet tropical climate conditions and is one of the major sediment contributors to the Great Barrier Reef. Study focus: The purpose of this paper was to identify soil erosion hotspots through simulating hydrological processes, soil erosion and sediment transport using the Soil and Water Assessment Tool (SWAT). In particular, we focused on predictive uncertainty in the model evaluations and presentations-a major knowledge gap for hydrology and soil erosion modelling in the context of Great Barrier Reef catchments. We carried out calibration and validation along with uncertainty analysis for streamflow and sediment at catchment and sub-catchment scales and investigated details of water balance components, the impact of slope steepness and spatio-temporal variations on soil erosion. The model performance in simulating actual evapotranspiration was compared with those of the Australian Landscape Water Balance (AWRA-L) model to increase our confidence in simulating water balance components. New hydrological insights for the region: The spatial locations of soil erosion hotspots were identified and their responses to different climatic conditions were quantified. Furthermore, a set of land use scenarios were designed to evaluate the effect of reforestation on sediment transport. We anticipate that protecting high steep slopes areas, which cover a relatively small proportion of the catchment (4-9\%), can annually reduce $15-26 \%$ sediment loads to the Great Barrier Reef.
\end{abstract}

Keywords: catchment modelling; uncertainty analysis; water balance; sediment; actual evapotranspiration

\section{Introduction}

The Great Barrier Reef (GBR) is the world's largest coral reef extending over $2000 \mathrm{~km}$ off the Queensland coastline. During the 20th century, the landscape of GBR catchments was altered dramatically as a result of expanding sugarcane, banana and livestock production. To expand agricultural lands and improve productivity, many natural waterways were replaced by drainage systems, native vegetative cover was removed, soil structure disturbed and natural wetlands emptied [1]. Vegetation clearance rules in Queensland were minimal until the mid-2000s when the enforcement of clearing restrictions came into effect to preserve remaining forests and native vegetative cover [2]. In tropical regions of Queensland, where there is a potential for high soil erosion, it is estimated that around half of its primary rainforests $\left(6700 \mathrm{~km}^{2}\right.$ of $\left.13,000 \mathrm{~km}^{2}\right)$ have been destroyed since the beginning of European colonisation [3,4]. These anthropogenic changes in GBR catchments have 
amplified soil erosion, increased sediment concentrations in the reef and consequently resulted in the degradation of the coral and seagrass ecosystems, which provide food and shelter for variety of marine species [5-9]. Specifically, the increased build-up of sediment in downstream waterbodies of GBR tropical catchments is likely to bring more ecological issues such as shrinking habitat and interstitial spaces, hence, disturbing the behaviour and lowering the survival rate of freshwater species [10].

Effective planning for controlling pollution and applying mitigation options necessitates improvement in our understanding of hydrological processes. Until now, various modelling efforts have been carried out to simulate streamflow and sediment loads flowing to the GBR including eWater Source and its plug-in, Dynamic SedNet, that have been developed and being used as industry standards for hydrology and water quality modelling for GBR catchments [11]. However, in most cases, details of the link between hydrological processes within catchments and delivered sediment loads to the GBR, as well as the uncertainty involved in model outputs and processes are not quantified [12-17]. Incorporating quantitative measures of uncertainty in a modelling approach reduces the effect of biases in the form of epistemic errors on decision making [18,19], increases our confidence in model outputs and eventually makes the approach more reliable for incorporating into ecological risk assessment $[20,21]$.

In this research, an advanced process-based catchment model-Soil and Water Assessment Tool (SWAT) [22] — has been applied for the first time in the context of GBR catchments for modelling hydrology and soil erosion. The model has capabilities in the spatial and temporal simulation of runoff generation, soil erosion, sediment transport, plant/vegetative growth and agricultural management practices in an integrated system, plus the availability of supporting documents and additional tools such as SWAT-CUP [23] for analysing uncertainty through inverse modelling and parallel processing. We established a SWAT model for the North Johnstone catchment (a tropical catchment in the north-east of Australia), listed as a priority catchment for controlling sediment delivery to the GBR [24]. The model is calibrated and validated for daily streamflow rate and daily sediment load at the catchment and sub-catchment scales. We obtained sediment concentration data from two independent studies for two separate periods reflecting different climatic conditions from extreme wet to extreme dry. We also carried out a parameter sensitivity analysis and quantified predictive uncertainty in model outputs for both water balance components and the soil erosion from major land uses.

Previous studies predicted that protecting degraded pastures through reforestation has the potential to increase soil water retention capacity, reduce runoff and stabilise soil, and therefore, control soil erosion and improve coral reef health [25-29]. In addition, recently, efforts have been made to investigate cost-effective methods of successful plant species selection for reforestation on degraded pastures in the upper section of North Johnstone catchment [30,31]. Here, we investigated four land use change scenarios for converting pasture areas to rainforests to quantify the extent to which reforestation can reduce sediment loads from the North Johnstone catchment to the GBR.

\section{Material and Methods}

\subsection{Study Area}

The North Johnstone catchment is located between latitudes $17^{\circ} 38^{\prime} \mathrm{S}$ and $17^{\circ} 16^{\prime} \mathrm{S}$ and longitudes $145^{\circ} 28^{\prime} \mathrm{E}$ and $146^{\circ} 4^{\prime} \mathrm{E}$ in the Wet Tropics Region in the northeast of Australia (Figure 1). This catchment covers an area of approximately 102,980 ha.

The catchment has wet tropical climate conditions which mean that during austral summers the weather is hot, and humid with frequent and intensive rainfall while in austral winters, temperatures and rainfall are relatively low. Rainfall gradient is remarkable across the catchment; $3600 \mathrm{~mm}$ mean annual rainfall at the coastal areas (e.g., Innisfail) while gradually decreasing to $2000 \mathrm{~mm}$ mean annual rainfall towards the upper section (e.g., Malanda).

Conserved natural rainforest and pasture areas (with native or modified vegetative cover under grazing or minimal uses) cover $37 \%$ and $51 \%$ of the catchment, respectively, and thus are the dominant 
land uses. Agricultural farms mostly comprise bananas (2.5\%) and sugarcane (3.5\%) which are located in the coastal zone. A marginal proportion (less than 1\%) can be attributed to tea farms and tropical fruit trees in the upper section. Other land uses are commercial/residential/industrial areas comprising $3 \%$ of the whole catchment and a small proportion is also related to the water surface and wetlands (see Figure 2a for the spatial distribution of land uses). Coastal areas have basalt and alluvium soils while the dominant soils in the upper areas are red ferrosols, dermosols and red kandosols.

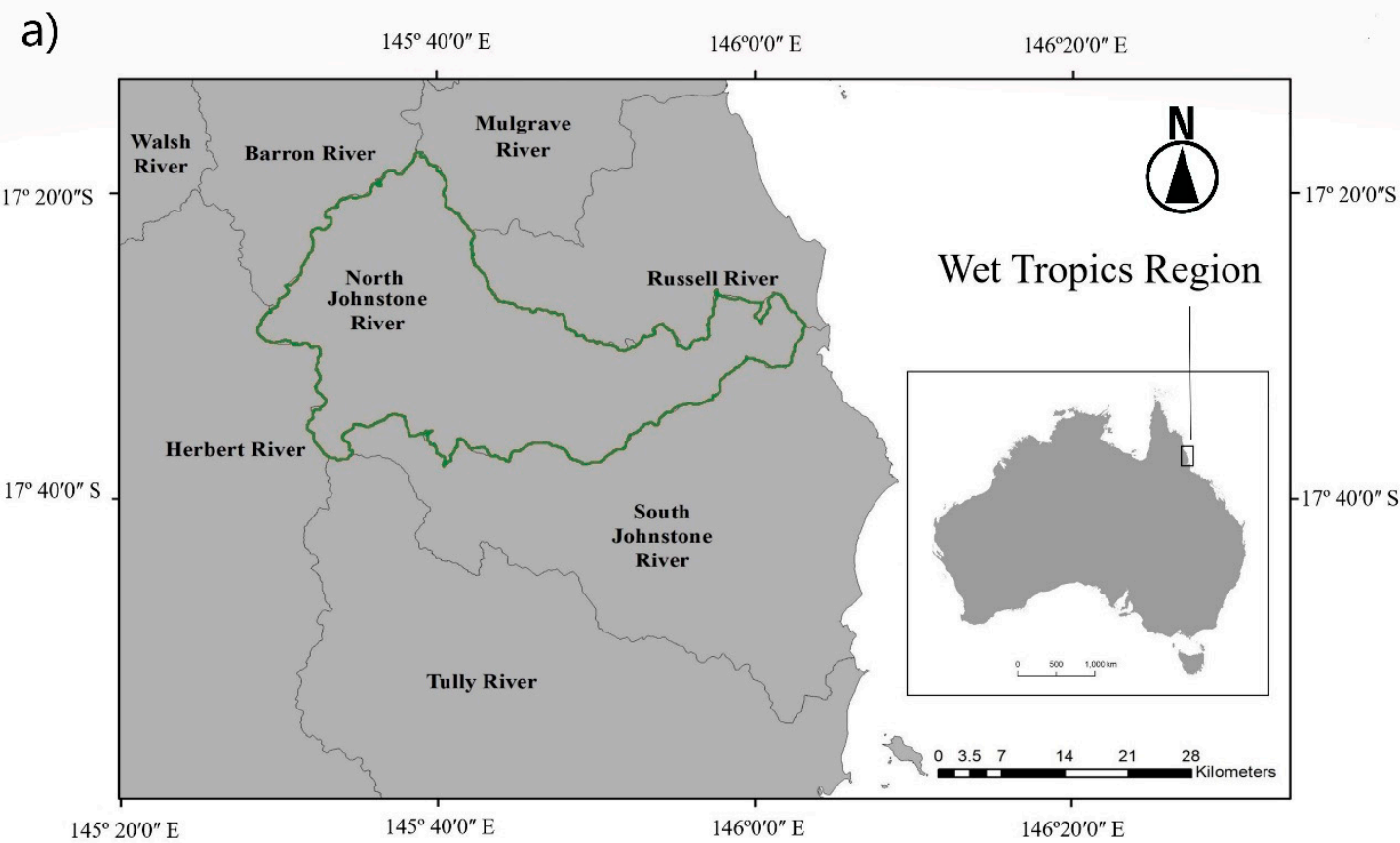

b)
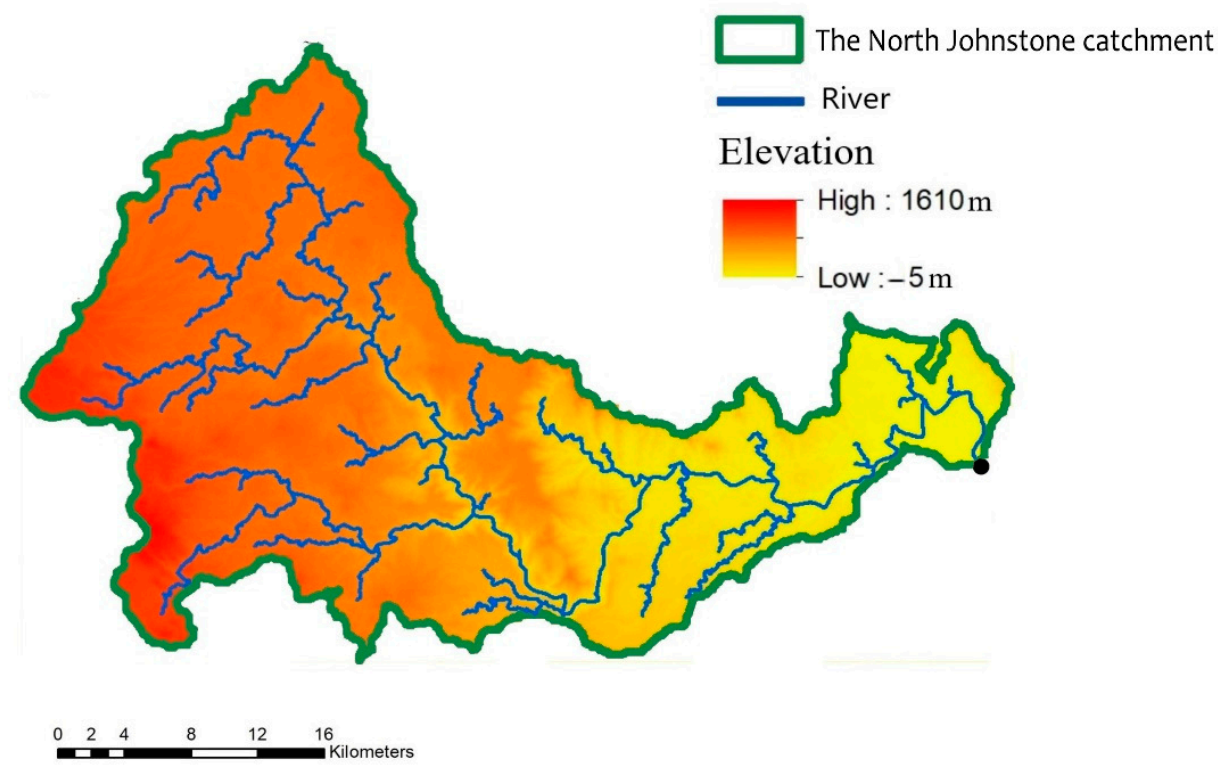

Figure 1. The location of the North Johnstone catchment and its adjacent catchments in the Wet Tropics Region (a) and the upscaled North Johnstone catchment showing its river network and elevation gradient (b).

\subsection{Soil and Water Assessment Tool (SWAT)}

SWAT is a process-based continuous daily time-step model, which enables users to simulate hydrological processes, crop growth, erosion, and pollutant transport in agricultural catchments to 
study the long-term impacts of the gradual build-up of pollutants on downstream water bodies [22]. SWAT has been applied successfully to various catchments with different type of environments around the world including tropical catchments in East Asia, Africa and South America [32-34].

SWAT is a semi-distributed model that delineates a catchment into sub-catchments and divides each sub-catchment into hydrologic response units (HRUs) based on uniform slope, land use and soil type. SWAT structure is built upon two main phases, i.e., land phase and channel phase.

In the land phase, SWAT computes water balance in each HRU and then aggregates the results to sub-catchment outputs based upon the fraction of each HRUs. SWAT calculates water balance in each HRUs based on the Equation (1).

$$
S W_{t}=S W_{0}+\sum_{i=1}^{\mathrm{t}}\left(R_{\text {day }}-Q_{\text {surf }}-E T_{a}-W_{\text {seep }}-Q_{g w}\right)
$$

where $S W_{t}$ is the final soil water content $(\mathrm{mm}), S W_{0}$ is the initial soil water content on day $i(\mathrm{~mm}), t$ is the time (days), $R_{\text {day }}$ is the amount of rainfall on day $i(\mathrm{~mm}), Q_{\text {surf }}$ is the amount of surface runoff on day $i(\mathrm{~mm}), E T_{a}$ is the amount of actual evapotranspiration on day $i(\mathrm{~mm}), W_{\text {seep }}$ is the amount of water entering the vadose zone from the soil profile on day $i(\mathrm{~mm})$ and $Q_{g w}$ is the amount of return flow on day $i(\mathrm{~mm})$.

To calculate surface runoff at daily time steps, SWAT uses the soil conservation service curve number (SCS) method [35]. The daily curve number can be calculated based on antecedent soil moisture or plant evapotranspiration of which the latter is selected for this research. For the computation of daily actual evapotranspiration, SWAT first needs to calculate potential evapotranspiration through one of the following methods: Penman-Monteith [36], Hargreaves [37] and Priestley-Taylor [38]. As wind data records are not available for the case study, potential evapotranspiration is simulated using the Priestley-Taylor method. This method requires solar radiation, air temperature and relative humidity. Further description regarding the details of the calculation of surface runoff, the movement of water in the vadose zone, $\mathrm{ET}_{\mathrm{a}}$ and groundwater recharge/discharge can be found in SWAT theoretical documentation [22].

To estimate sediment yield, SWAT employs the Modified Universal Soil Loss Equation (M M ULE, Equation (2)) [39]. While Universal Soil Loss Equation (USLE) predicts average annual gross erosion as a function of rainfall energy, in $M_{U S L E}$ the rainfall energy factor is replaced with a runoff factor, which improves the sediment yield prediction, eliminates the need for delivery ratios, and allows the equation to be applied to individual storm events [40]. Nevertheless, $M_{U S L E}$ accounts for soil losses caused by sheet, rill, and rain splash but not the erosion caused by landslides and gullies. However, only 3\% of sediment loads in the whole Wet Tropic Region comes from gully erosion while $70 \%$ and $27 \%$ of sediment come, respectively, from hillslope and stream bank erosion [24].

$$
\text { Sed }=11.8 \times\left(Q_{\text {surf }} \cdot q_{\text {peak }} \cdot \text { area } a_{h r u}\right)^{0.56} \cdot K_{\text {USLE }} \cdot C_{U S L E} \cdot P_{U S L E} \cdot L S_{U S L E} \cdot C F R G
$$

where Sed is the sediment yield on a given day $\left(\mathrm{t} \cdot \mathrm{ha}^{-1}\right), Q_{\text {surf }}$ the surface runoff volume $(\mathrm{mm}), q_{\text {peak }}$ is the peak runoff rate $\left(\mathrm{m}^{3} / \mathrm{s}\right)$, area $a_{h r}$ is the area of the HRU (ha), $K_{U S L E}$ is the $M_{U S L E}$ soil erodibility factor $\left(0.013\right.$ metric ton $\mathrm{m}^{2} \mathrm{hr} /\left(\mathrm{m}^{3}\right.$ - metric ton $\left.\left.\mathrm{cm}\right)\right), C_{U S L E}$ is the $M_{\text {USLE }}$ cover and management factor, $P_{U S L E}$ is the $M_{U S L E}$ support practice factor, $L S_{U S L E}$ is the $M_{U S L E}$ topographic factor and CFRG is the coarse fragment factor.

In the channel phase, SWAT routes sub-catchment outputs through a river reach in the channel network to the output/s of the catchment. SWAT has five stream power equations for calculating maximum sediment concentration, modelling bank and bed erosions in a channel containing various bed materials and sediment disposition. In this study, due to the lack of data regarding the floodplain and the material of the channel bed, the simplified version of Bagnold [41] is used to calculate the maximum amount of sediment that can be transported in a stream segment. The Bagnold stream 
power equation calculates the maximum sediment concentration based on Equation (3) and then calculates deposition and degradation by comparing the sediment concentration in the channel and the calculated maximum sediment concentration based on Equations (4) and (5).

$$
\text { Conc }_{s e d, c h, m x}=c_{s p} \cdot v_{c h, p k}^{s p e x p}
$$

If

$$
\text { Conc }_{\text {sed, } c h, i}>\text { Conc }_{\text {sed, ch, max }} \operatorname{Sed}_{d e p}=\left(\text { Conc }_{s e d, c h, i}-\text { Conc }_{s e d, c h, m x}\right) \cdot V_{c h}
$$

If

$$
\text { Conc }_{\text {sed, ch, } i}<\text { Conc }_{\text {sed, ch, max }} \operatorname{Sed}_{\text {deg }}=\left(\text { Conc }_{\text {sed,ch, } m x}-\text { Conc }_{s e d, c h, i}\right) \cdot V_{c h} \cdot K_{C H} \cdot C_{C H}
$$

where $\mathrm{Conc}_{s e d, c h, m x}$ is the maximum amount of sediment that can be transported $(\mathrm{kg} / \mathrm{L}), v_{c h, p k}$ is the peak channel velocity $(\mathrm{m} / \mathrm{s})$ while $c_{s p}$ is a coefficient (SPCON), spexp is an exponent (SPEXP), Conc $c_{s e d, c h, i}$ is the concentration of sediment in time step $\mathrm{i}(\mathrm{kg} / \mathrm{L}), K_{C H}$ is the channel erodibility factor (CH_COV1), $V_{c h}$ is the volume of water in the reach segment $\left(\mathrm{m}^{3}\right)$ and $C_{C H}$ is the channel cover factor (CH_COV2).

\subsection{Model Input Data}

Specific information regarding climate, soil properties, topography, vegetation cover and land use management practices are required by SWAT to directly simulate physical processes associated with hydrology, erosion, sediment transport and crop/plant growth for the catchment. The summary of

\begin{tabular}{|c|c|c|c|}
\hline Data & Scale & Detail & Source of Data \\
\hline $\begin{array}{l}\text { Digital Elevation } \\
\text { Model }\end{array}$ & $25 \mathrm{~m}$ & Elevation, Slope and Length & $\begin{array}{l}\text { The State of Queensland, Department of } \\
\text { Natural Resources, Mines and Energy } \\
\text { (https://data.qld.gov.au/dataset/digital- } \\
\text { elevation-models-25metre-by- } \\
\text { catchment-areas-series) }\end{array}$ \\
\hline Land use map & $\begin{array}{c}\text { 1:50,000 } \\
\text { (Figure 2b) }\end{array}$ & $\begin{array}{l}\text { Land use of the region, } \\
\text { version } 8 \text { classification }\end{array}$ & $\begin{array}{l}\text { Queensland Land Use Mapping } \\
\text { Program, Australian Bureau of } \\
\text { Agricultural and Resource Economics } \\
\text { and Sciences [42] (https: } \\
\text { //www.qld.gov.au/environment/land/ } \\
\text { vegetation/mapping/qlump-datasets) }\end{array}$ \\
\hline Soil map & $\begin{array}{c}1: 250,000 \\
22 \text { separated soil profiles }\end{array}$ & $\begin{array}{l}\text { Physical properties for soil } \\
\text { profiles including soil } \\
\text { erodibility factor (USLE_k) } \\
\text { dataset }\end{array}$ & $\begin{array}{l}\text { Australian Soil Resource Information } \\
\text { System, level } 4 \text { specification [43] } \\
\text { (http://www.asris.csiro.au/) }\end{array}$ \\
\hline Watercourses & & $\begin{array}{l}\text { Watercourse, connector, } \\
\text { stream, river, creek, gully, } \\
\text { canal, drain, channel, } \\
\text { drainage }\end{array}$ & $\begin{array}{l}\text { The state of Queensland, Department of } \\
\text { Natural Resources, Mines and Energy, } \\
2018 \text { (https: } \\
\text { //data.qld.gov.au/dataset/watercourse- } \\
\text { identification-map-queensland-series) }\end{array}$ \\
\hline Climate & $\begin{array}{l}6 \text { stations }(1980-2012) \\
(\text { Figure } 2 d)\end{array}$ & $\begin{array}{l}\text { Daily precipitation }(\mathrm{mm}), \\
\text { maximum } / \text { minimum } \\
\text { temperature }\left({ }^{\circ} \mathrm{C}\right), \text { relative } \\
\text { humidity }(\%) \text { and solar } \\
\text { radiation }\left(\mathrm{MJ} / \mathrm{m}^{2}\right)\end{array}$ & $\begin{array}{c}\text { Gridded data of SILO (scientific } \\
\text { information for land owners) } \\
\text { (https://silo.longpaddock.qld.gov.au/ } \\
\text { point-data) }\end{array}$ \\
\hline
\end{tabular}
model input data is provided in Table 1.

Table 1. Summary of model input data.

\subsubsection{Hydrological Observation Data}

Daily records of streamflow rate for the calibration period (1991-1996) and validation period (2007-2012) for three monitoring stations were obtained from the Queensland Government Water Monitoring Information portal (https://water-monitoring.information.qld.gov.au/) (see Figure $2 \mathrm{~d}$ for the location of stream gauges). 
Tung Oil station (112004A) is located at the end of the North Johnstone River receiving runoff from 92,500 ha- $90 \%$ of the whole catchment. Glen Allyn (112003A) is located at the upper section of the catchment on the North Johnstone river receiving water from 16,500 ha (mostly pasture)-16\% of the whole catchment. Fisher Creek Station (112002A) is located on a tributary channel receiving runoff from $1500 \mathrm{~h}-1.5 \%$ of the whole catchment—of pasture, rainforest, sugarcane and banana farms.

\subsubsection{Sediment Loads Observation Data}

Daily sediment concentration data for the period between 1991 and 1996 were obtained from a previous study carried out in the region by Hunter and Walton [13]; they collected sediment concentration samples in 188 days at the Tung Oil station, 149 days at the Glenn Allyn station and 113 days at Fisher Creek station. After Hunter and Walton [13], there was not any sediment monitoring until 2007 when the Queensland Department of Environment and Science started monitoring sediment concentration; however, this time only for the Tung Oil station. We used the sediment concentration data of this program for the validation period (2007-2012) in which sediment concentration samples recorded for 94 days.

To calculate sediment loads, we multiplied the average sediment concentration by the average streamflow rate of a day. Depending on the number of collected samples on a given day, this method of calculating sediment loads, like any other method, can result in underestimation or overestimation [44]. Therefore, we considered $30 \%$ error in calculated sediment loads. This error range was used for calculating P-factor described in Section 2.6.1.

\subsection{Actual Evapotranspiration Database}

Actual evapotranspiration $\left(\mathrm{ET}_{\mathrm{a}}\right)$ is the major mechanism of removing water from any catchment while greatly influencing water balance components of the system. We compared $\mathrm{ET}_{\mathrm{a}}$ estimation of SWAT with an external source of $\mathrm{ET}_{\mathrm{a}}$ to increase our confidence in modelling water balance components. For this purpose, we obtained $\mathrm{ET}_{\mathrm{a}}$ from the Australian Landscape Water Balance (AWRA-L) (http://www.bom.gov.au/water/landscape). AWRA-L v6 [45] is a $5 \mathrm{~km} \times 5 \mathrm{~km}$ gridded water balance model which provides daily estimates of $\mathrm{ET}_{\mathrm{a}}$ across Australia from 2005.

We selected three locations to compare $\mathrm{ET}_{\mathrm{a}}$ including one pasture dominated area in the upper section with high altitude $(765 \mathrm{~m})$ and annual rainfall of $1900 \mathrm{~mm}$ (Figure 2d, location 1), one rainforest dominated area located in the midsection with low altitude $(230 \mathrm{~m})$ and high annual rainfall $(3800 \mathrm{~mm})$ (Figure 2d, location 2) and one mixed area of rainforest and pasture in the upper section with high altitude $(1400 \mathrm{~m})$ and moderate rainfall $(2500 \mathrm{~mm})$ (Figure $2 \mathrm{~d}$, location 3).

\subsection{SWAT Model Setup}

\subsubsection{Model Setup}

SWAT2012 revision 670 was applied for this research, which was the latest version available at the time. Based on the DEM map, SWAT delineated the catchment into 91 sub-catchments and finally defined 1503 HRUs based on slope classifications, soil types and land use (see Figure 2). The SWAT model was set up for daily time step with 7 years as a warm-up/equilibrium period according to recommendations by Daggupati et al. [46]. 


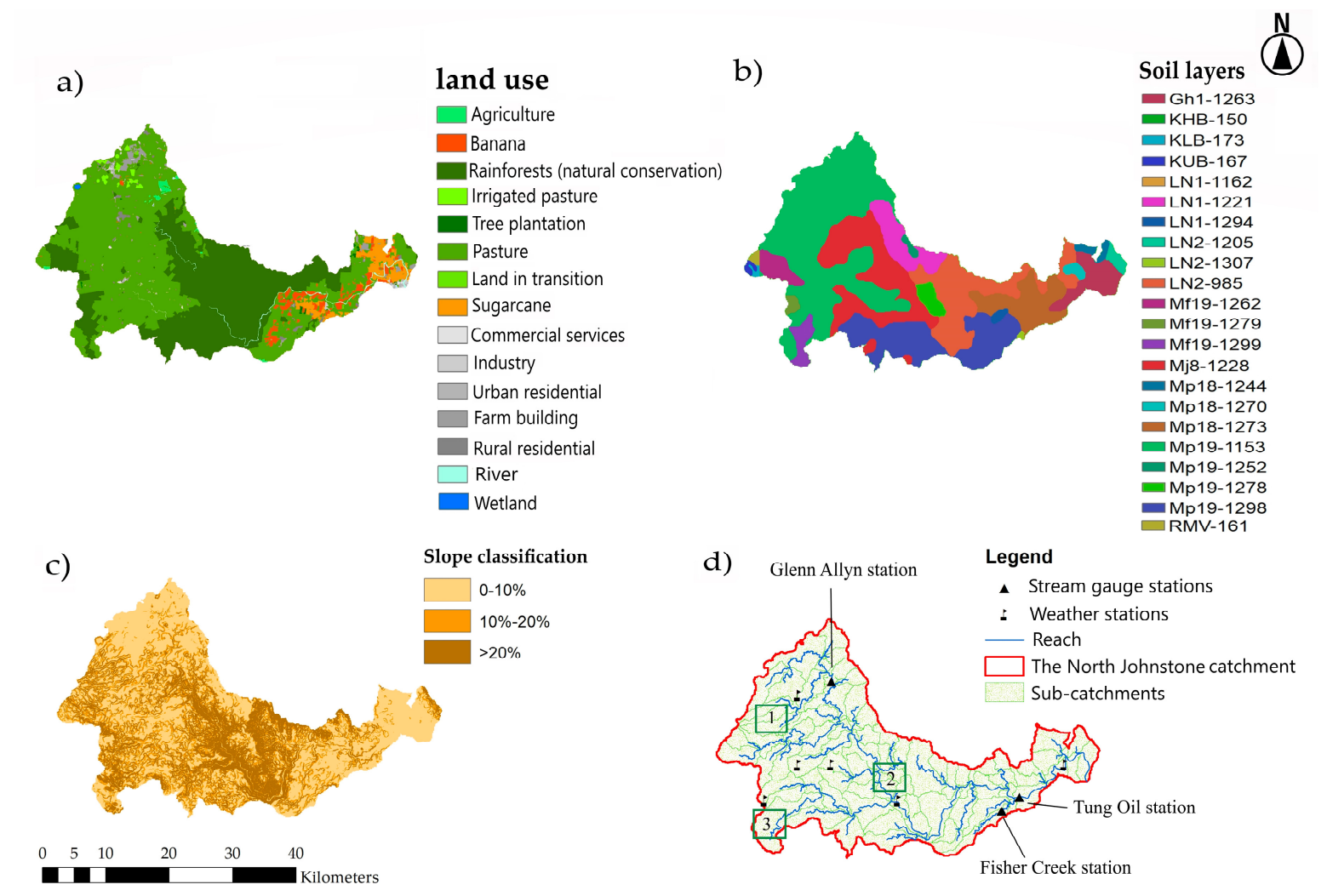

Figure 2. (a) land use map, (b) soil layer map, (c) slope classification and (d) catchment details including the location of weather stations, monitoring stations, catchment outlet, river and streams. Legends of the soil layers represent their soil feature names and associated feature ID numbers in the ASRIS database in which the Gh1 is red smooth-ped earths moderately undulating lands; KHB is Krasnozems of the undulating and rolling hills on; KLB is Krasnozems of the basalt lava plains; KUB is Krasnozems of the undulating basalt lava plains; LN1 is pale loams with a smooth-ped B horizon; LN2 is pale loams with a smooth-ped B horizon, high hills; Mf19 is yellow smooth-ped earths, strongly undulating; Mj8 is red smooth-ped earths, hilly high plateau; Mp18 is red smooth-ped earths, moderately undulating lands; Mp19 is red smooth-ped earths, low hilly to hilly basalt; RMV is red podzolics of the steep hills and mountains.

\subsubsection{Parameterisation of the Vegetative Cover}

Seasonal changes to the vegetative cover have a great influence on biomass production, runoff, actual evapotranspiration and soil erosion and SWAT requires specific parameters of leaf area index (LAI) of plants and crops during the growing cycle to simulate their seasonal development.

For the pasture areas, we adjusted the leaf area index (LAI) parameters of SWAT plant dataset to simulate LAI of pasture plant as much as possible close to a processed time series we retrieved from MODIS Collection 6 (MODIS15A2H) remote sensing data (http://reverb.echo.nasa.gov/) for Location $1 \mathrm{in}$ the upper section of the catchment (Figure 2d). The maximum LAI of pasture plant, maximum potential biomass, and potential heat units are, respectively, considered to be $3 \mathrm{~m}^{2} / \mathrm{m}^{2}, 10 \mathrm{t} \cdot \mathrm{ha} \mathrm{h}^{-1}$ and 2000.

LAI parameters of sugarcane plant are adjusted based on one study for a widely known genotype of sugarcane in Mexico with rainfed conditions [47] and two comprehensive studies for assessing and modelling yield and LAI expansion of Australian sugarcane $[48,49]$. The maximum LAI of sugarcane plant, maximum potential biomass, and potential heat units are, respectively, considered to be $6.5 \mathrm{~m}^{2} / \mathrm{m}^{2}, 90 \mathrm{t} \cdot \mathrm{ha}^{-1}$ and 5500 . We also considered one plant and two ratoons for sugarcane cultivation. Planting was considered to take place between September and November, and the first harvesting would happen in the next 12 months. For the two subsequent ratoons, we considered that 
harvesting would happen in the next 10 months; $90 \%$ of sugarcane biomass would be removed at ratooning events, and $10 \%$ of the removed biomass would remain on the surface as residue. Among sugarcane HRUs, different planting years are also considered to keep the heterogeneity of the time of agricultural activities in the region.

For bananas, we checked the seasonal change in LAI values with a previous study for tropical bananas [50], considering the maximum LAI up to $4.5 \mathrm{~m}^{2} / \mathrm{m}^{2}$, while having around $100 \mathrm{t} \cdot \mathrm{ha} \mathrm{a}^{-1}$ biomass in full maturity and gaining 30-50 $\mathrm{t} \cdot \mathrm{ha}^{-1} \cdot \mathrm{year}^{-1}$ after harvesting/ratooning with potential heat units of 5500 .

The LAI of the rainforest is below $5 \mathrm{~m}^{2} / \mathrm{m}^{2}$, which is (as a result of frequent cyclones in the region) relatively lower comparing to other rainforests across the world [51]. Thus, rainforest LAI parameters were adjusted to have a mostly consistent LAI of $4.5 \mathrm{~m}^{2} / \mathrm{m}^{2}$ and an average biomass of $200 \mathrm{t} \cdot \mathrm{ha}^{-1}$.

\subsection{Model Calibration and Validation}

\subsubsection{Measuring the Model Performance}

Based on suggestions by Moriasi et al. [52], two dimensionless statistical indicators-Nash Sutcliff efficiency (NSE) and the ratio of root mean square error to the standard deviation of the observations (RSR) - and one error index - percent bias (PBIAS) — were used to measure the goodness of fit of the best simulation during calibration and validation. NSE indicates a "very good" performance (for both streamflow and sediment) when it is more than 0.75 and "unsatisfactory" when it is less than 0.5; RSR indicates a "very good" performance (for both streamflow and sediment) when it is less than 0.5 and "unsatisfactory" when it is more than 0.7. However, for streamflow, when PBIAS is less than $\pm 10 \%$, it indicates very good performance and unsatisfactory when it is more than $\pm 25 \%$. For sediment loads, PBIAS less than $\pm 15 \%$ shows a "very good" performance and "unsatisfactory" when it is more than $\pm 55 \%$.

We also used two indicators for evaluating the overall performance of the predictive uncertainty in model outputs including P-factor which is the percentage of observation ( \pm error) captured by $95 \%$ prediction uncertainty (95PPU) and R-factor which is the thickness of the 95PPU envelope [53]. The range of P-factor is between 0 and 1 and the range of R-factor is between 0 and infinity. A P-factor close to 1 and R-factor less than 1 confirm the acceptable performance of the model.

\subsubsection{Model Calibration}

The calibration, validation, sensitivity and uncertainty analyses are carried out by employing the sequential uncertainty fitting algorithm-version 2 (SUFI-II)—an inverse modelling procedure based on Latin hypercube sampling [54] developed by Abbaspour et al. [55].

SUFI-II starts by assuming a large parameter uncertainty within a physically justifiable range, so that the measured data initially fall within the 95PPU, then reduce the uncertainty in the next step based on fitted parameters found for the best simulation in the previous step [53]. Overall, with SUFI-II, we repeat these steps several times for calibration until the simulations capture most of our observations in the 95PPU envelope (P-factor 1 ) while reaching to a small envelope (R-factor $<1$ ) of simulations.

Furthermore, before conducting calibration/validation, we carried out a one-at-a-time sensitivity analysis for each parameter followed by several global sensitivity analyses for a number of combinations of parameters to identify the most sensitive ones involved in hydrological processes, erosion and sediment transport for the case study. Table 2 shows a description of the parameters that have been selected for the model calibration. 
Table 2. Identified sensitive parameters involved in hydrological processes, soil erosion and sediment transport in the Soil and Water Assessment Tool (SWAT) model.

\begin{tabular}{|c|c|}
\hline Parameters & Description \\
\hline \multicolumn{2}{|r|}{ Groundwater and baseflow } \\
\hline GW_DELAY & Groundwater delay \\
\hline GWQMN & Threshold depth of water in the shallow aquifer required for return flow to occur \\
\hline ALPHA_BF & Baseflow recession coefficient \\
\hline \multicolumn{2}{|r|}{ Evapotranspiration } \\
\hline GW_REVAP & Groundwater revap * coefficient \\
\hline CANMX & Maximum canopy storage \\
\hline REVAPMN & Threshold depth of water in the shallow aquifer for revap to occur \\
\hline EPCO & Plant uptake compensation factor \\
\hline \multicolumn{2}{|r|}{ Runoff and Streamflow } \\
\hline SOL_K & Saturated soil conductivity \\
\hline CH_K1 & Effective hydraulic conductivity in tributary channel \\
\hline CH_K2 & Effective hydraulic conductivity in the main channel \\
\hline CH_N1 & Manning's " $n$ " value for tributary channels \\
\hline CH_N2 & Manning's " $n$ " value for the main channel \\
\hline $\mathrm{CN} 2$ & SCS daily curve number \\
\hline OV_N & Manning's " $n$ " value for overland flow \\
\hline \multicolumn{2}{|r|}{ Soil erosion parameters } \\
\hline USLE_K & USLE soil erodibility factor \\
\hline USLE_C & USLE cover and management factor \\
\hline USLE_P & USLE support practice factor \\
\hline \multicolumn{2}{|r|}{ Sediment transportation } \\
\hline SPCON & Coefficient in sediment transport equation \\
\hline SPEXP & Exponent in sediment transport equation \\
\hline CH_COV1 & Channel erodibility factor \\
\hline CH_COV2 & Channel cover factor \\
\hline
\end{tabular}

${ }^{*}$ Water that moves from shallow aquifer to the overlying unsaturated zone.

To maintain the heterogeneity of hydrological processes within the model, some of these parameters were regionalised and considered adaptive to land uses. For example, ALPHA_BF and SOL_K were regionalised for two sections of the catchment. The upper section includes 35 sub-catchments and is pasture dominated with lower rainfall. The second section, including the coastal zone and the midsection of the catchment, a high annual rainfall region, consists of 56 sub-catchments. In addition, other parameters such as CN2, OV_N and USLE_C were considered to be different for four groups of land use (pasture, rainforest, sugarcane and banana). The initial range of values for USLE_C of pasture, rainforests, banana and sugarcane farms were obtained from Armour et al. [14] for the region.

To take into account the processes involved in groundwater contribution to baseflow, an automated baseflow separation and recession analysis technique developed by Arnold et al. [56] was used to separate baseflow and streamflow during calibration. This automated separation procedure can also estimate the initial range for ALPHA_BF, which was used to route the groundwater recharge to the stream.

After identifying sensitive parameters, the model was calibrated for daily streamflow and sediment loads for the three stations for the period between 1991 and 1996. The model was then validated for the six-year period between 2007 and 2012 for streamflow of the three stations and daily sediment loads of Tung Oil station. For the subsequent analyses on water balance components and soil erosion, the model was executed for a 22-year period between 1991 and 2012 and 500 iterations using parameters range found in calibration. 
We divided the recorded annual rainfall of the catchment into three statistical intervals. The first interval represents extreme dry years with annual rainfall less than mean minus one standard deviation (annual rainfall less than $2298 \mathrm{~mm}$ ); the second interval represents normal years with annual rainfall within plus one and minus one standard deviation of the mean (annual rainfall between $2295 \mathrm{~mm}$ and $3928 \mathrm{~mm}$ ); and the third interval represents extreme wet years with annual rainfall more than mean plus one standard deviation (more than $3928 \mathrm{~mm}$ ). Accordingly, the calibration period consists of five normal years (1991 and 1993-1996) and one extreme dry year (1992 with $2250 \mathrm{~mm}$ annual rainfall); the validation period consists of five normal years (2007-2009 and 2011-2012) and one extreme wet year (2010 with $4214 \mathrm{~mm}$ annual rainfall). For the whole 22 years of simulation, 1999 was the most extreme wet year (5151 mm annual rainfall) and 2002 was the most extreme dry year (1467 mm annual rainfall).

\section{Results}

\subsection{Model Calibration and Validation Results}

Table 3 shows the global parameter sensitivity analysis for the calibration period (the smaller of $p$-value and larger absolute value of t-state determine the sensitivity ranking of the parameters). The parameters including USLE_C for pasture areas, USLE_K for the whole of the region, CH_N1 for all tributary channels in the region, USLE_C for farmlands (banana and sugarcane), $\mathrm{CH}$-K1 for all tributary channels, CN2 and OV_N for pasture areas have the highest sensitivity. Generally, the parameters in the $M_{U S L E}$ have higher sensitivity because the observed data for sediment are fewer than those of streamflow. Additionally, pasture areas cover the highest proportion of the catchment, thus, although the soil erosion from farmlands is higher, much of the sediment loads is contributed by pasture areas, thus justifying the highest sensitivity of the model to USLE_C for pasture areas. The other parameters such as $\mathrm{CN} 2$, OV_N and CH_K1 also show high sensitivities since calculating peak flows (events that carry the highest amount of sediment) is highly dependent on the value of these parameters.

Figure 3 shows the results of calibration and uncertainty analyses of streamflow. Most of the observations at either catchment scale or sub-catchment scale are captured by the 95PPU (P-factor ranges from 0.85 to 0.93 ) with an acceptable band thickness (R-factor ranges from 0.55 to 0.74 ). Moreover, the model performance statistic measures (NSE, RSR and PBIAS) show a very good agreement between the best simulations and the observations. Also, the small extracted graphs in Figure 3 clearly show that the event peak flows and daily baseflow observations are well captured by SWAT simulations.

Figure 4 shows the results of sediment calibration and uncertainty quantification. More than $77 \%$ of all observed sediment loads are captured by the simulations at the Tung Oil station and the Glenn Allyn station with an acceptable band thickness (R-factor is 0.53 and 0.70 , respectively). Reasonable agreements are also achieved between the best simulation and observation for these two stations as NSE values are more than 0.6, RSR values are less than 0.65 and absolute values for PBIAS are less than 25\% (see Figure 4a,b). While the P-factor and NSE for Fisher Creek station is not desirable, the calibration performance for this station is still acceptable given the small drainage area of Fisher Creek station and the inherent errors in recording sediment concentrations and calculating sediment loads for such a sub-catchment with short lag time in the hydrograph. It should be noted that but most of the extreme sediment loads are captured by 95PPU (Figure 4c). 
Table 3. Results of global parameter sensitivity analysis with Nash Sutcliff efficiency (NSE) as the objective function, including the lower and upper bound of parameters and the fitted value.

\begin{tabular}{|c|c|c|c|c|c|c|c|}
\hline \multirow{2}{*}{ Parameters } & \multirow{2}{*}{$\begin{array}{l}\text { Sensitivity } \\
\text { Ranking }\end{array}$} & \multicolumn{2}{|c|}{ Sensitivity } & \multirow{2}{*}{$\begin{array}{c}\text { Land } \\
\text { Use/Sub-Catchments }\end{array}$} & \multirow{2}{*}{$\begin{array}{l}\text { Lower } \\
\text { Bound }\end{array}$} & \multirow{2}{*}{$\begin{array}{l}\text { Upper } \\
\text { Bound }\end{array}$} & \multirow{2}{*}{$\begin{array}{l}\text { Fitted } \\
\text { Value }\end{array}$} \\
\hline & & $p$-Stat & $t$-Stat & & & & \\
\hline USLE_C & 1 & 0.00 & -38.81 & Pasture & 0.01 & 0.03 & 0.01 \\
\hline USLE_K* & 2 & 0.00 & -16.80 & All land uses & -0.2 & 0 & -0.20 \\
\hline CH_N1 & 3 & 0.00 & 16.48 & All sub-catchments & 0.1 & 0.2 & 0.13 \\
\hline USLE_C & 4 & 0.00 & -10.55 & $\begin{array}{l}\text { Banana and } \\
\text { sugarcane }\end{array}$ & 0.01 & 0.08 & 0.06 \\
\hline CH_K1 & 5 & 0.00 & 9.00 & All sub-catchments & 0 & 50 & 27.29 \\
\hline CN2 & 6 & 0.00 & -7.33 & Pasture & 50 & 65 & 52.58 \\
\hline OV_N & 7 & 0.00 & 3.39 & Pasture & 0.2 & 0.4 & 0.34 \\
\hline SOL_K* & 8 & 0.04 & 2.06 & $\begin{array}{l}\text { Midsection and } \\
\text { coastal zone } \\
\text { sub-catchments }\end{array}$ & -0.2 & 0 & -0.16 \\
\hline ALPHA_BF & 9 & 0.04 & 2.02 & $\begin{array}{l}\text { Upper section } \\
\text { sub-catchments }\end{array}$ & 0.03 & 0.1 & 0.06 \\
\hline CH_N2 & 10 & 0.05 & 1.93 & All sub-catchments & 0.01 & 0.04 & 0.03 \\
\hline CH_COV2 & 11 & 0.07 & -1.85 & All sub-catchments & 0.01 & 0.04 & 0.02 \\
\hline USLE_C & 12 & 0.10 & -1.63 & Rainforest & 0.001 & 0.006 & 0.00 \\
\hline USLE_P & 13 & 0.11 & -1.60 & Banana & 0.8 & 1 & 0.80 \\
\hline SPCON & 14 & 0.13 & -1.52 & All sub-catchments & 0.001 & 0.005 & 0.00 \\
\hline CN2 & 15 & 0.13 & -1.52 & Rainforest & 45 & 60 & 53.27 \\
\hline GWQMN & 16 & 0.14 & 1.49 & All sub-catchments & 500 & 1000 & 836.17 \\
\hline ALPHA_BF & 17 & 0.18 & 1.33 & $\begin{array}{l}\text { Midsection and } \\
\text { coastal zone } \\
\text { sub-catchments }\end{array}$ & 0.03 & 0.1 & 0.05 \\
\hline $\mathrm{CN} 2$ & 18 & 0.22 & 1.23 & Banana & 70 & 85 & 79.27 \\
\hline SOL_K* & 19 & 0.22 & 1.22 & $\begin{array}{l}\text { Upper section } \\
\text { sub-catchments }\end{array}$ & -0.1 & 0.1 & -0.06 \\
\hline OV_N & 20 & 0.30 & 1.04 & Banana & 0.05 & 0.09 & 0.08 \\
\hline GW_DELAY & 21 & 0.32 & 1.00 & All sub-catchments & 50 & 350 & 284.50 \\
\hline CN2 & 22 & 0.32 & -0.99 & Sugarcane & 70 & 85 & 83.63 \\
\hline CH_COV1 & 23 & 0.34 & -0.96 & All sub-catchments & 0.01 & 0.04 & 0.02 \\
\hline $\mathrm{CH} \_\mathrm{K} 2$ & 24 & 0.61 & 0.51 & All sub-catchments & 20 & 70 & 59.17 \\
\hline SPEXP & 25 & 0.73 & 0.35 & All sub-catchments & 0.8 & 1.2 & 0.90 \\
\hline GW_REVAP & 26 & 0.76 & 0.31 & All sub-catchments & 0.01 & 0.2 & 0.41 \\
\hline REVAPMN & 27 & 0.78 & -0.27 & All sub-catchments & 200 & 500 & 556.70 \\
\hline EPCO & 28 & 0.91 & -0.11 & All sub-catchments & 0.7 & 0.9 & 0.79 \\
\hline OV_N & 29 & 0.97 & -0.04 & Rainforest & 0.1 & 0.4 & 0.19 \\
\hline USLE_P & 30 & 0.96 & 0.05 & Sugarcane & 0.8 & 1 & 0.80 \\
\hline OV_N & 31 & 0.96 & 0.05 & Sugarcane & 0.1 & 0.2 & 0.10 \\
\hline
\end{tabular}

* Indicates a relative change in the initial value of the parameter (we multiply the value presented in this table to the initial value to get the final value). The values of other parameters without* are those replacing the initial values. 
a)

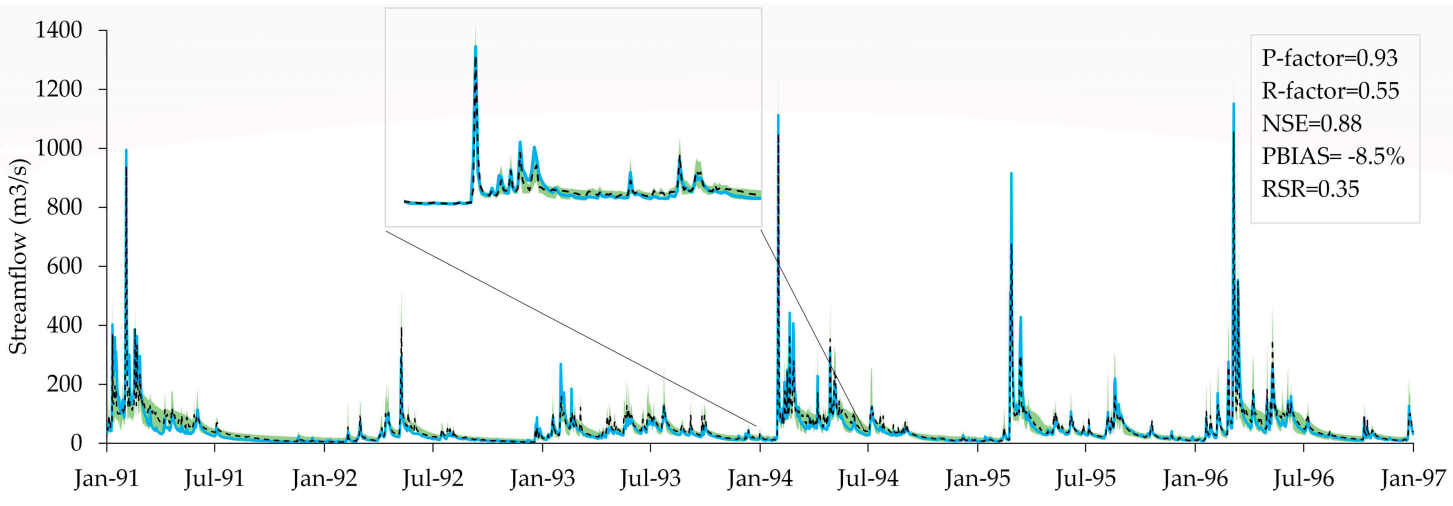

b)

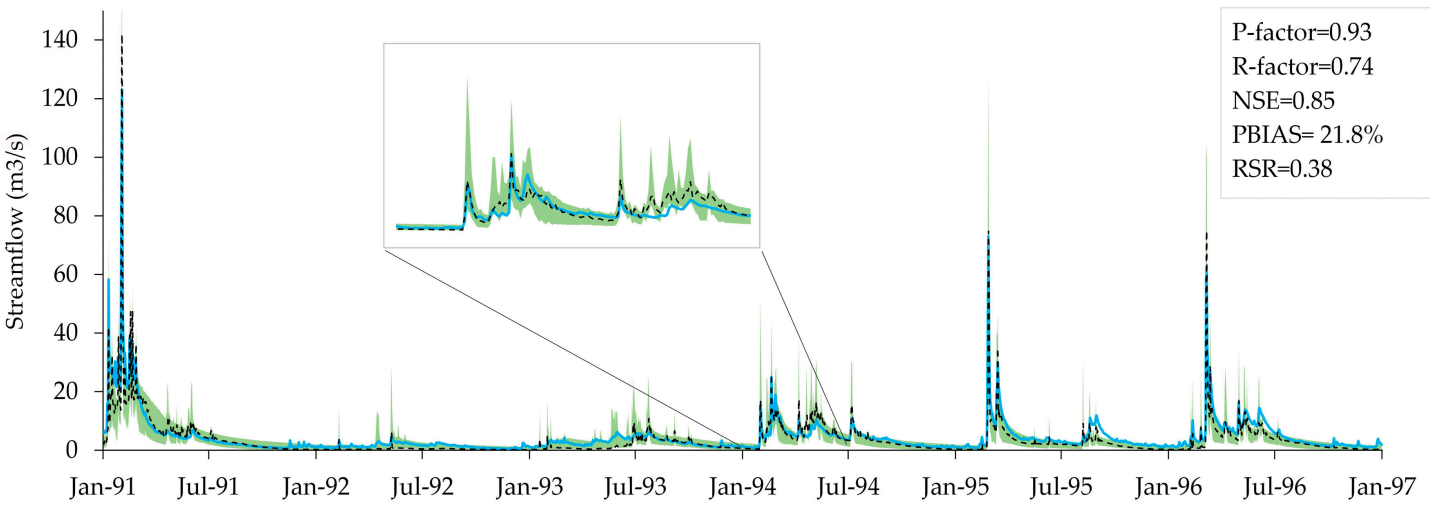

C)

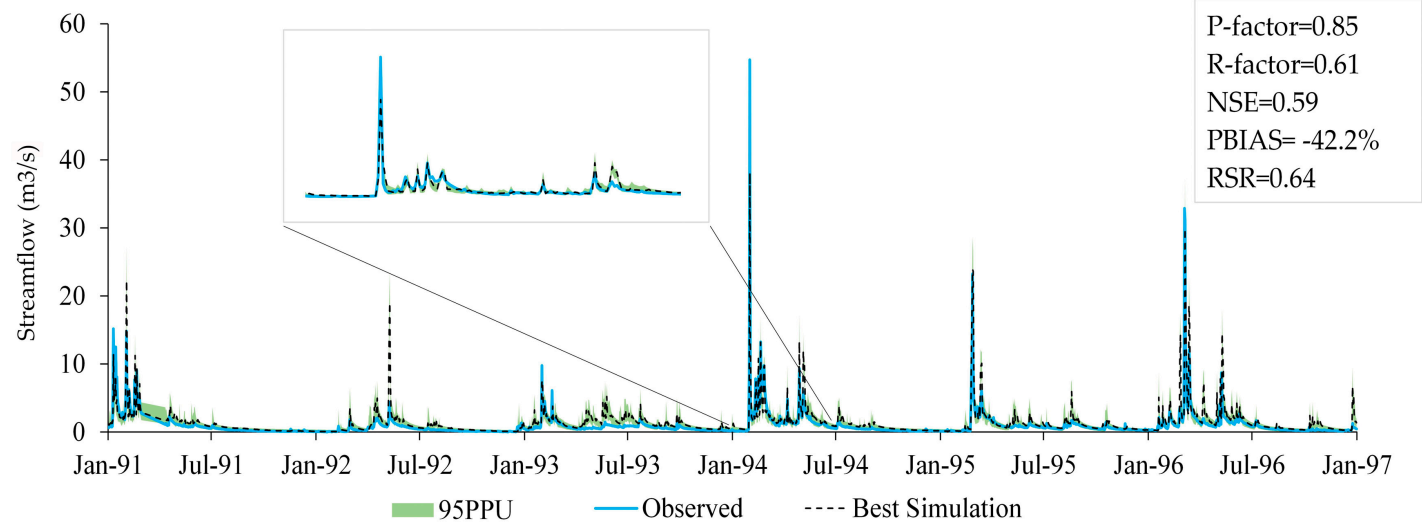

Figure 3. Streamflow calibration and uncertainty analysis: (a) Tung Oil station near the outlet of the catchment, (b) Glenn Allyn station in the upper section, and (c) Fisher Creek station. 
a)

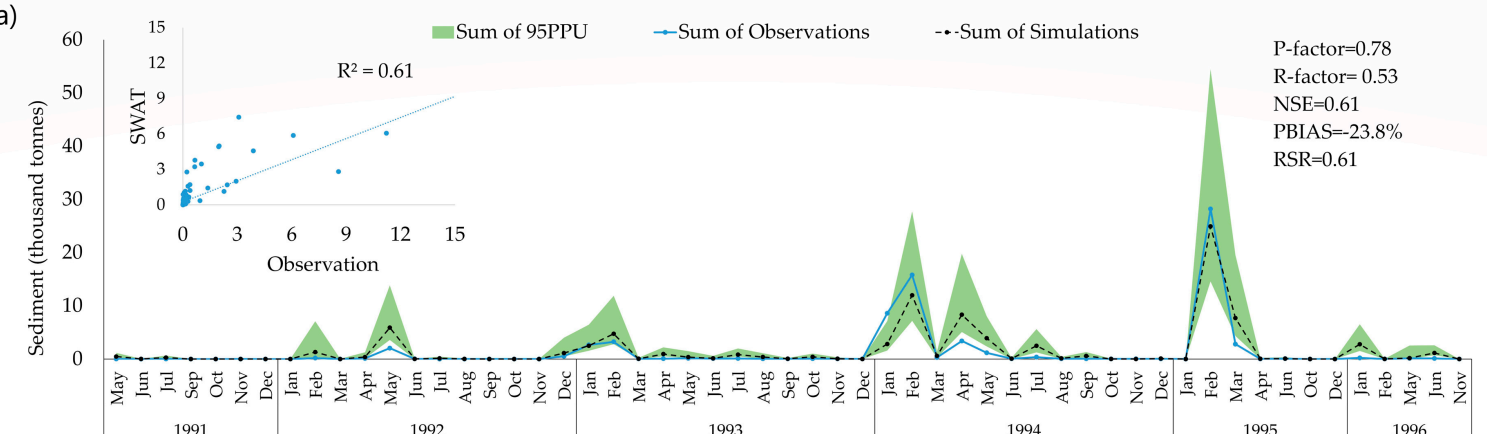

b)

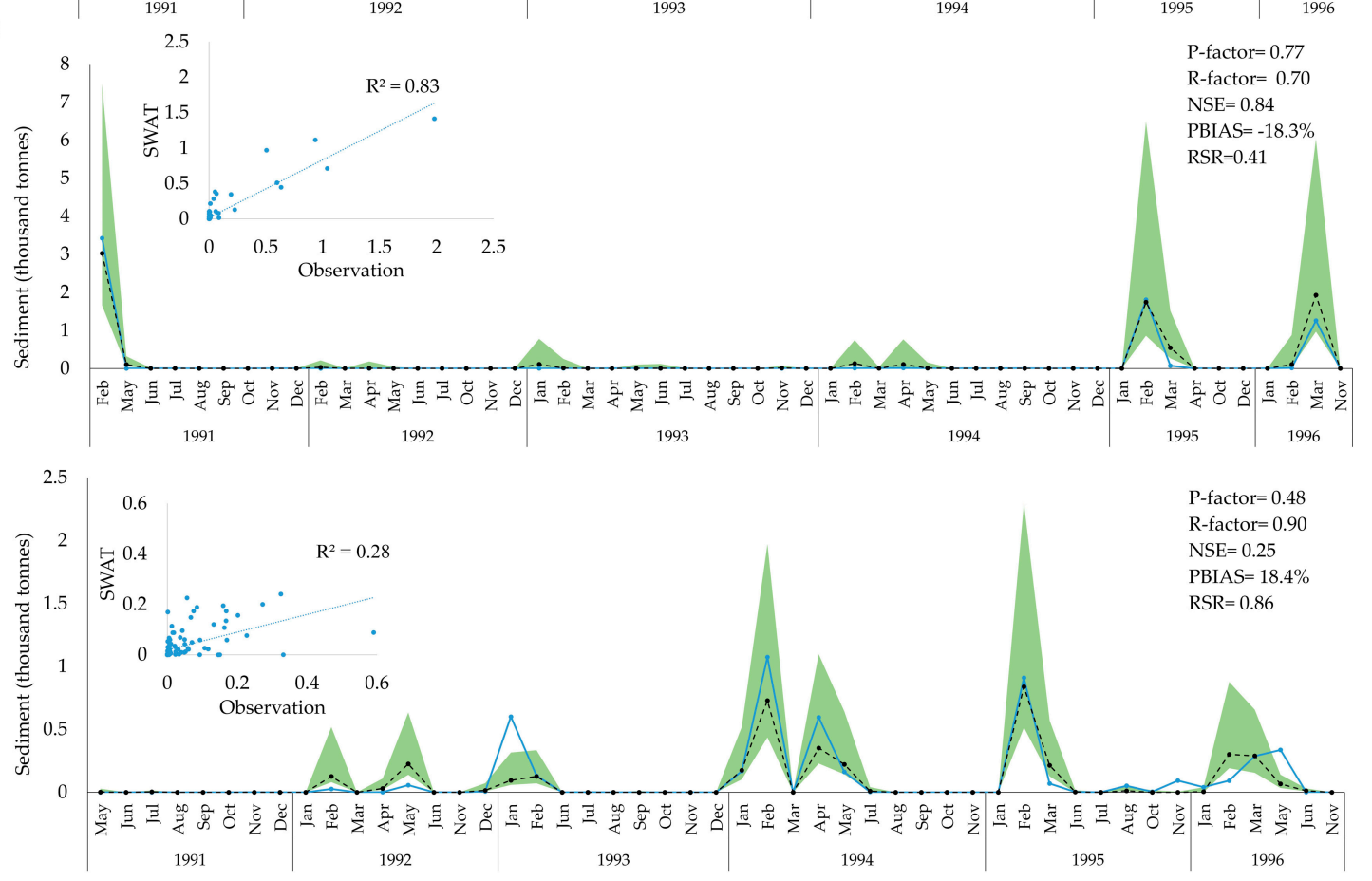

Figure 4. Results of calibration for sediment loads, showing aggregated values for each month in the calibration period of the best simulation, 95PPU, and the observation. The scatter plots show the best simulation versus the observation while the main graphs represent the monthly aggregated sediment loads: (a) Tung Oil station, (b) Glenn Allyn station, and (c) Fisher Creek station.

Figure 5 shows the results of the best streamflow simulation (using fitted values found from the best simulation in the calibration period) and uncertainty analysis (using the parameter range found from the calibration) for the validation period (2007-2012). Acceptable 95PPU was achieved for all gauging stations with P-factor ranging from 0.78 to 0.92 and R-factor ranging from 0.45 to 0.58 . In addition, the best simulation predicted a reasonable estimation relative to observation for all gauging stations for the validation period (NSE between 0.62 and 0.87 , RSR between 0.43 and 0.63 and PBIAS between -5 and $33 \%$ ). The small extracted graphs in Figure 5 clearly show that the peak flows and daily base flow observations are well simulated by the model.

Similarly, as shown in Figure 6, good model predictive performance was achieved for sediment loads for the Tung Oil station-the only sediment monitoring station-as P-factor is 0.70 and R-factor is 0.44 while for the best simulation the NSE is 0.9 , PBIAS is $12.5 \%$ and RSR is 0.56 . 

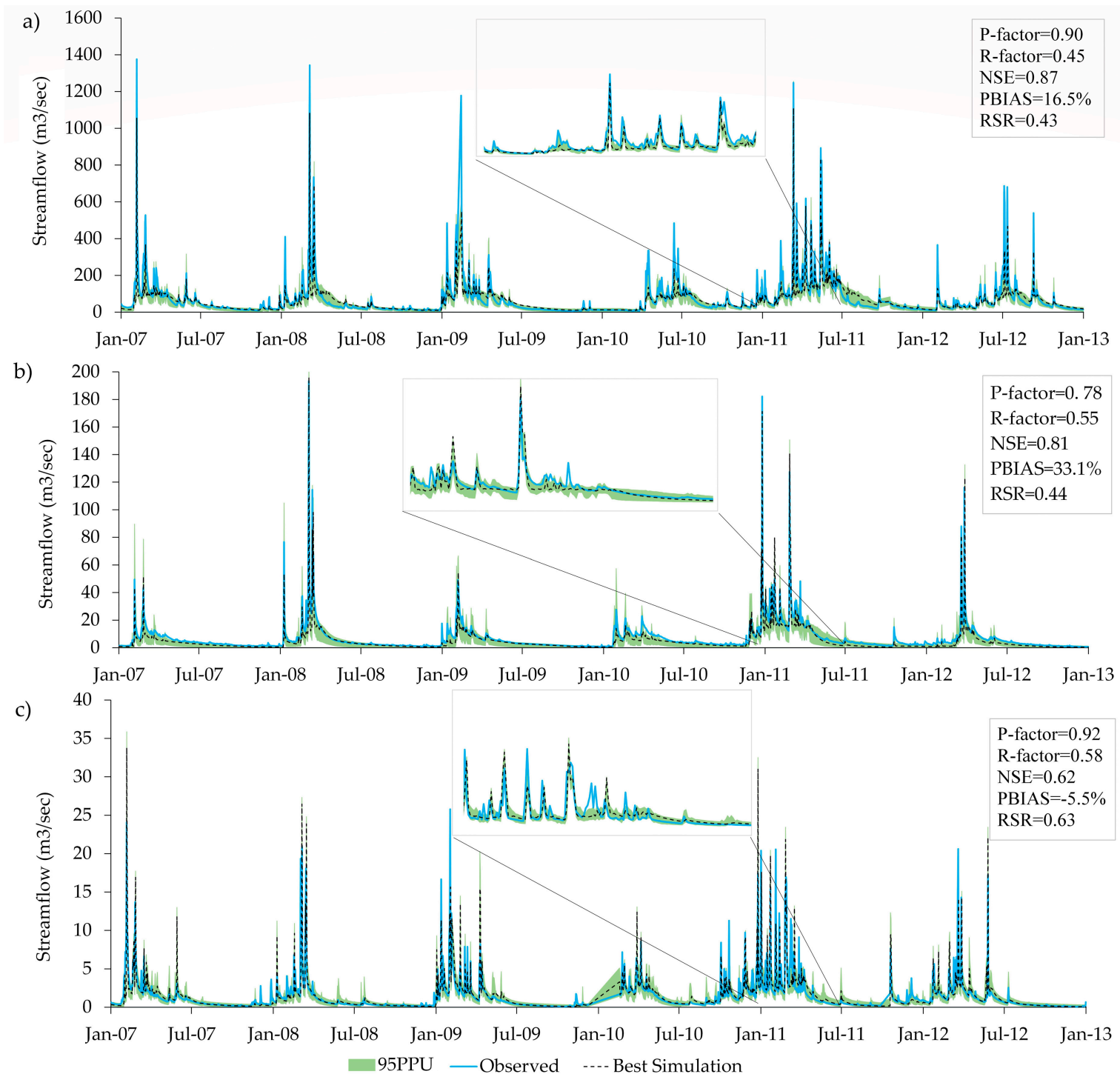

Figure 5. Daily streamflow validation (the period between 2007 and 2012) and 95PPU: (a) Tung Oil station; (b) Glenn Allyn station; and (c) Fisher Creek station.

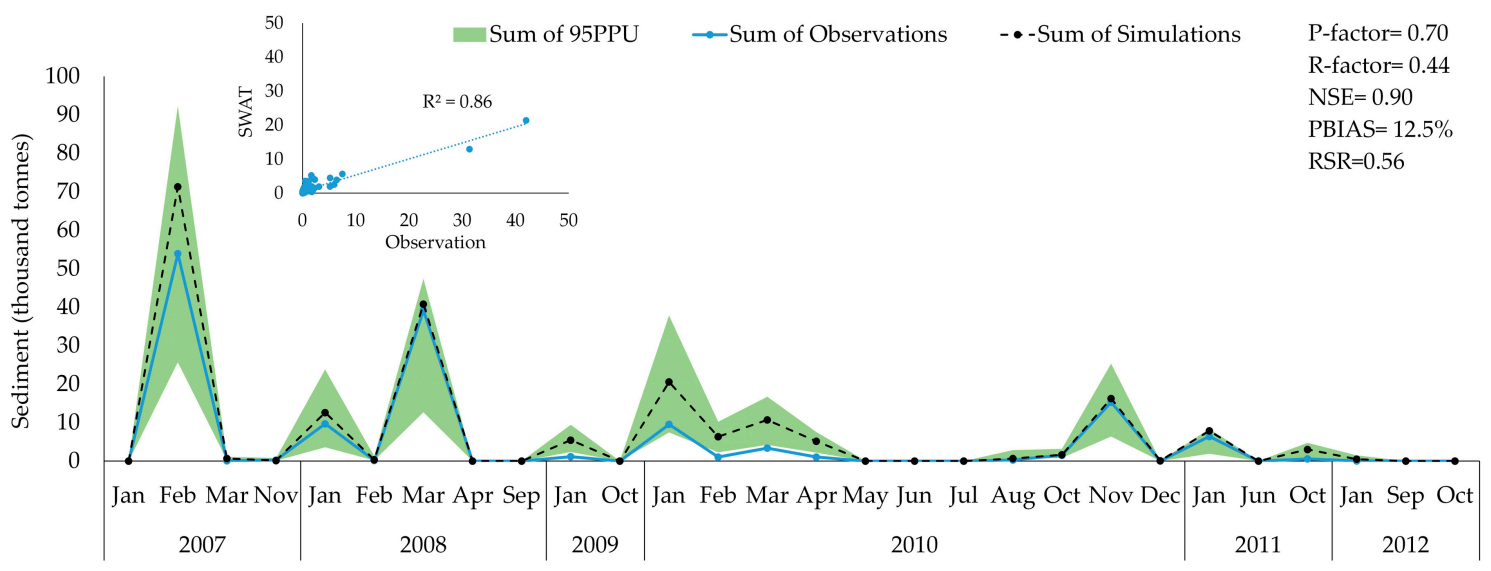

Figure 6. Results of validation and uncertainty analysis for sediment loads, showing aggregated values for each month of the best simulation, 95PPU, and the observation in the period between 2007 and 2012 at the Tung Oil station. The scatter plots show the best simulation versus the observation while the main graphs represent the monthly aggregated sediment loads. 


\subsection{Water Balance and Sediment Budget}

Table 4 shows the 95PPU and the annual average values for simulated water balance components over the 22 years of simulation. The results show that the average annual rainfall falling within the catchment is $3113 \mathrm{~mm}$ of which about $36 \%$ returns to the atmosphere through evapotranspiration. Predicted annual water yield is between 1860 and $2208 \mathrm{~mm}$ of which $977-1400 \mathrm{~mm}$ is surface runoff (around $31-44 \%$ of the whole rainfall), $248-292 \mathrm{~mm}$ is lateral flow, $469-855 \mathrm{~mm}$ and $35-48 \mathrm{~mm}$ are, respectively, return flows from shallow groundwater and deep aquifers and $12-313 \mathrm{~mm}$ leaves the system by transmission losses.

Table 4. The 95PPU and average amounts of water balance components at the catchment scale for 22 years (1991-2012) where 95PPU is the result of 500 simulations. Rainfall is the average of six weather stations based on the area they represent.

\begin{tabular}{cccc}
\hline Water Balance Components & Minimum (2.5\%) & Average & Maximum (97.5\%) \\
\hline Rainfall $(\mathrm{mm})$ & 3113 & 3113 & 3113 \\
Surface runoff (mm) & 977 & 1224 & 1400 \\
Lateral flow (mm) & 248 & 270 & 292 \\
Shallow groundwater return flow (mm) & 469 & 657 & 855 \\
Deep groundwater return flow (mm) & 35 & 42 & 48 \\
REVAP (capillary flow) (mm) & 8.4 & 146 & 285 \\
Deep aquifer recharge (mm) & 35 & 42 & 47 \\
Total aquifer recharge (mm) & 717 & 902 & 959 \\
Total water yield (mm) & 1860 & 2027 & 2208 \\
Percolation (mm) & 561 & 669 & 829 \\
ET (mm) & 1045 & 1104 & 1165 \\
Transmission losses (mm) & 12 & 168 & 313 \\
Annual soil erosion (t/ha) & 0.7 & 1.29 & 2.13 \\
\hline
\end{tabular}

As illustrated in Figure 7, during summer months (November to April), the difference between rainfall and total amount of water leaving the catchment (water yield and $\mathrm{ET}_{\mathrm{a}}$ ) is positive which indicates recharging groundwater and increasing stored water in soil. During the winter months (May to October), this value is negative, indicating a reduction in stored water in soil and the contribution of groundwater return flow to baseflow.

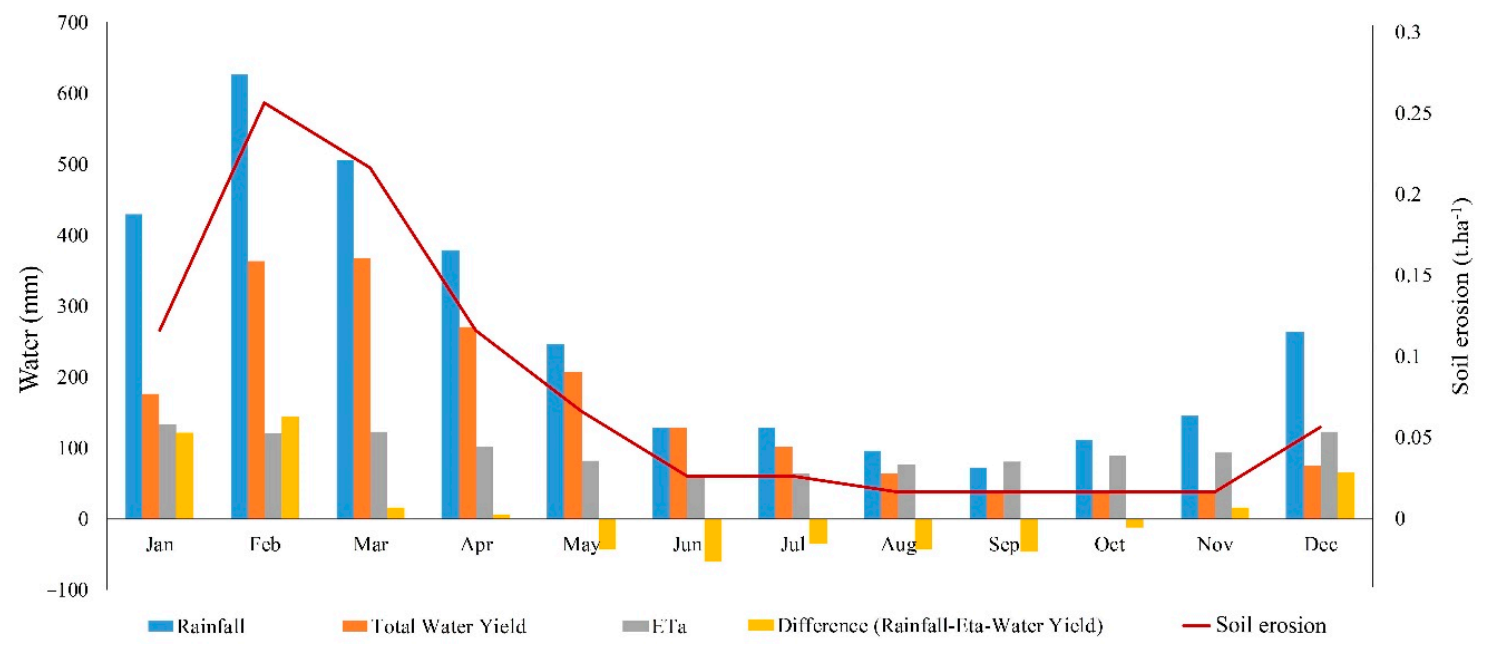

Figure 7. Average monthly rainfall, total water yield, actual evapotranspiration and sediment yield at catchment scale for 22 years simulation period (1991-2012) and 500 simulations.

The simulated average annual soil erosion rate of the North Johnstone catchment ranges from 0.7 to $2.13 \mathrm{t} \cdot \mathrm{ha}^{-1}$. The average monthly water balance and soil erosion rate show a close correlation between 
water yield and soil erosion, with the highest soil erosion rate $\left(0.25 \mathrm{t} \cdot \mathrm{ha}^{-1}\right)$ in February, the month with the highest water yield and rainfall (Figure 7).

The spatial distribution of average annual surface runoff, groundwater return flow, $\mathrm{ET}_{\mathrm{a}}$ and rainfall in the North Johnstone catchment with respect to standard deviation are depicted in Figure 8. Our simulation results show that annual $\mathrm{ET}_{\mathrm{a}}$ in the upper section with high altitude is between 886 and $1077 \mathrm{~mm}$ and annual $\mathrm{ET}_{\mathrm{a}}$ in the midsection (rainforest dominated area) is between 1239 and $1489 \mathrm{~mm}$. The results of the SWAT simulation show that rainforest dominated areas support the baseflow and a significant amount of groundwater return flow is generated from the rainforest areas in the middle section of the catchment while the upper section seldom contributes to baseflow.

a)

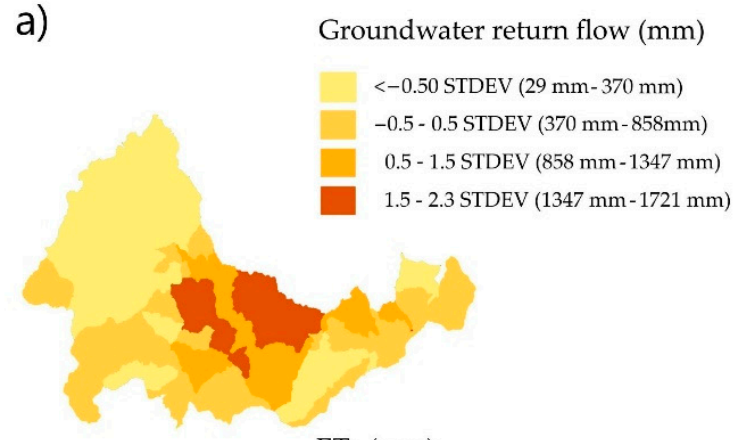

c)

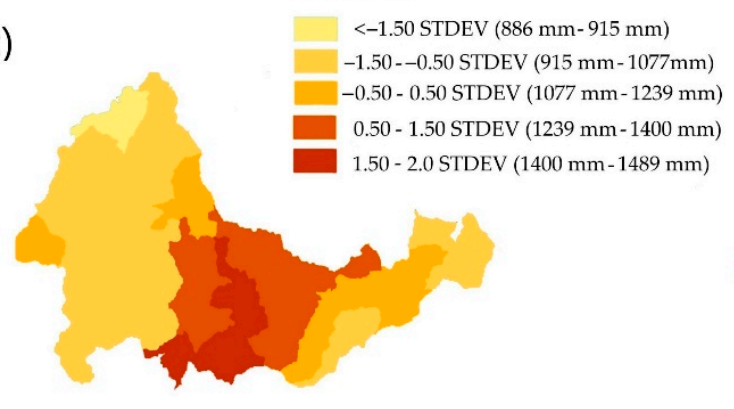

b) Surface runoff $(\mathrm{mm})$
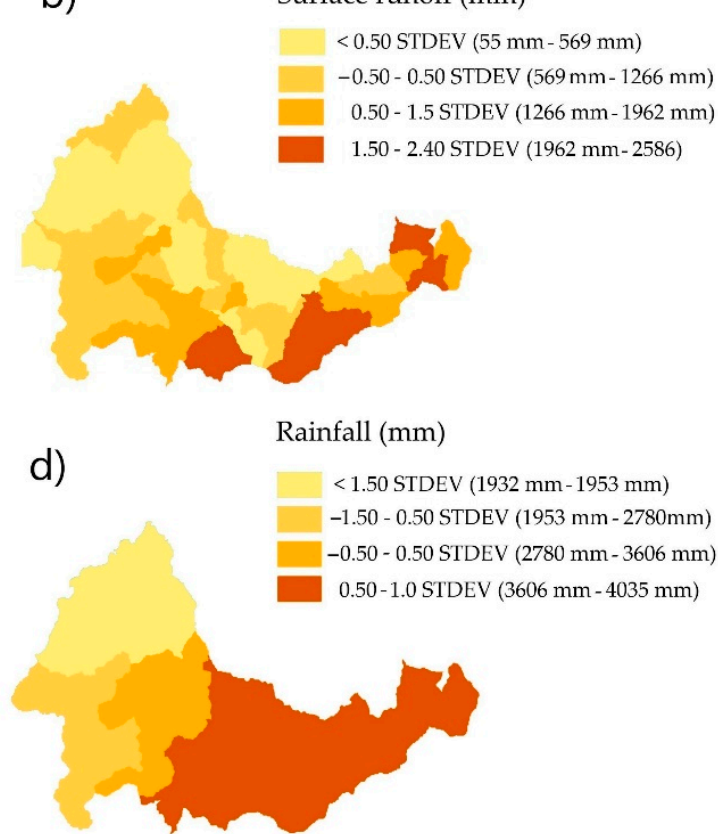

Figure 8. Spatial average annual amount of (a) groundwater return flow, (b) surface runoff, (c) $\mathrm{ET}_{\mathrm{a}}$, and (d) rainfall with respect to the standard deviation (STDEV).

\subsection{SWAT Performance in Simulating $E T_{a}$ Compared to AWRA-L}

Average annual $\mathrm{ET}_{\mathrm{a}}$ simulated by SWAT for the pasture dominated area (Figure 9a) is between $794 \mathrm{~mm}$ and $961 \mathrm{~mm}$, for the rainforest dominated location (Figure $9 \mathrm{~b}$ ) is between $1400 \mathrm{~mm}$ to $1485 \mathrm{~mm}$ and for the mixed pasture and rainforest location (Figure 9c) is between $872 \mathrm{~mm}$ and $1016 \mathrm{~mm}$. For the same order, $\mathrm{ET}_{\mathrm{a}}$ by AWRA-L is estimated at $1089 \mathrm{~mm}, 1332 \mathrm{~mm}$ and $1071 \mathrm{~mm}$. A direct comparison between SWAT and AWRA-L is not applicable as they are modelling $\mathrm{ET}_{\mathrm{a}}$ at different scales with different methods for estimating potential ET and water balance; however, the monthly $\mathrm{ET}_{\mathrm{a}}$ values simulated by SWAT are underestimated for location 1 and 3 (PBIAS values are respectively 16.1\% and $8.0 \%$ ), and overestimated for location 2 (with PBIAS of $-8.3 \%$ ) relative to monthly $\mathrm{ET}_{\mathrm{a}}$ values simulated by AWRA-L. 


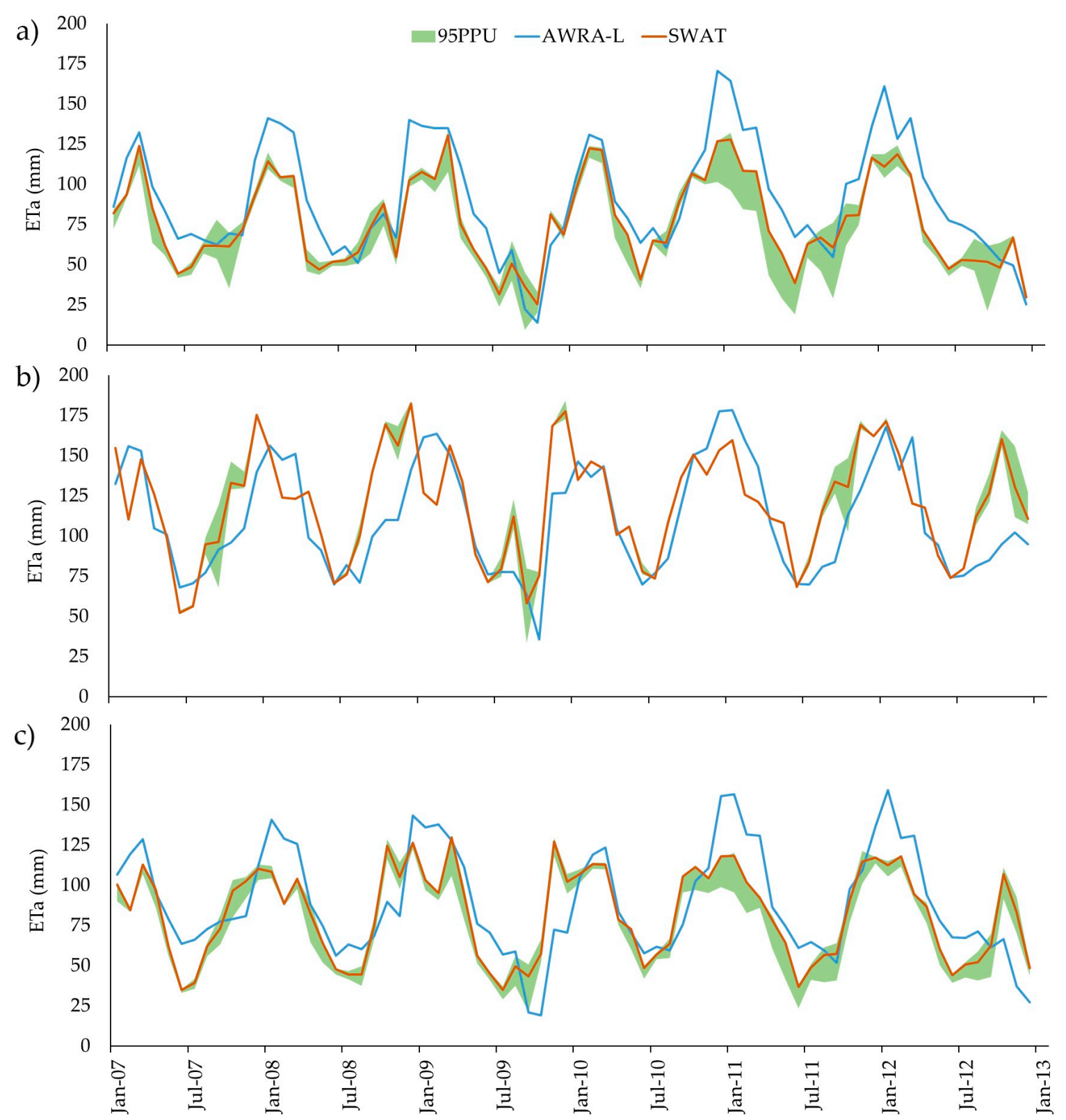

Figure 9. Monthly $\mathrm{ET}_{\mathrm{a}}$ simulated by SWAT and AWRA-L. (a) is the pasture dominated area, (b) is the rainforest dominated area and (c) is the mixed pasture and rainforest area.

\subsection{Soil Erosion}

Figure 10 shows simulated annual time series of soil erosion with 95PPU for (a) banana HRUs (b) pasture HRUs (c) sugarcane HRUs and (d) rainforest HRUs over the 22 years of simulation (1991-2012). The 95PPU here represents the annual weighted average of soil erosion among the HRUs with the same land use based on their total land use area. Among the land uses, banana HRUs appear to have the highest annual soil erosion rate and associated predictive uncertainty, following by pasture HRUs and sugarcane HRUs. The rainforest HRUs appear to have lowest annual soil erosion as well as predictive uncertainty. 

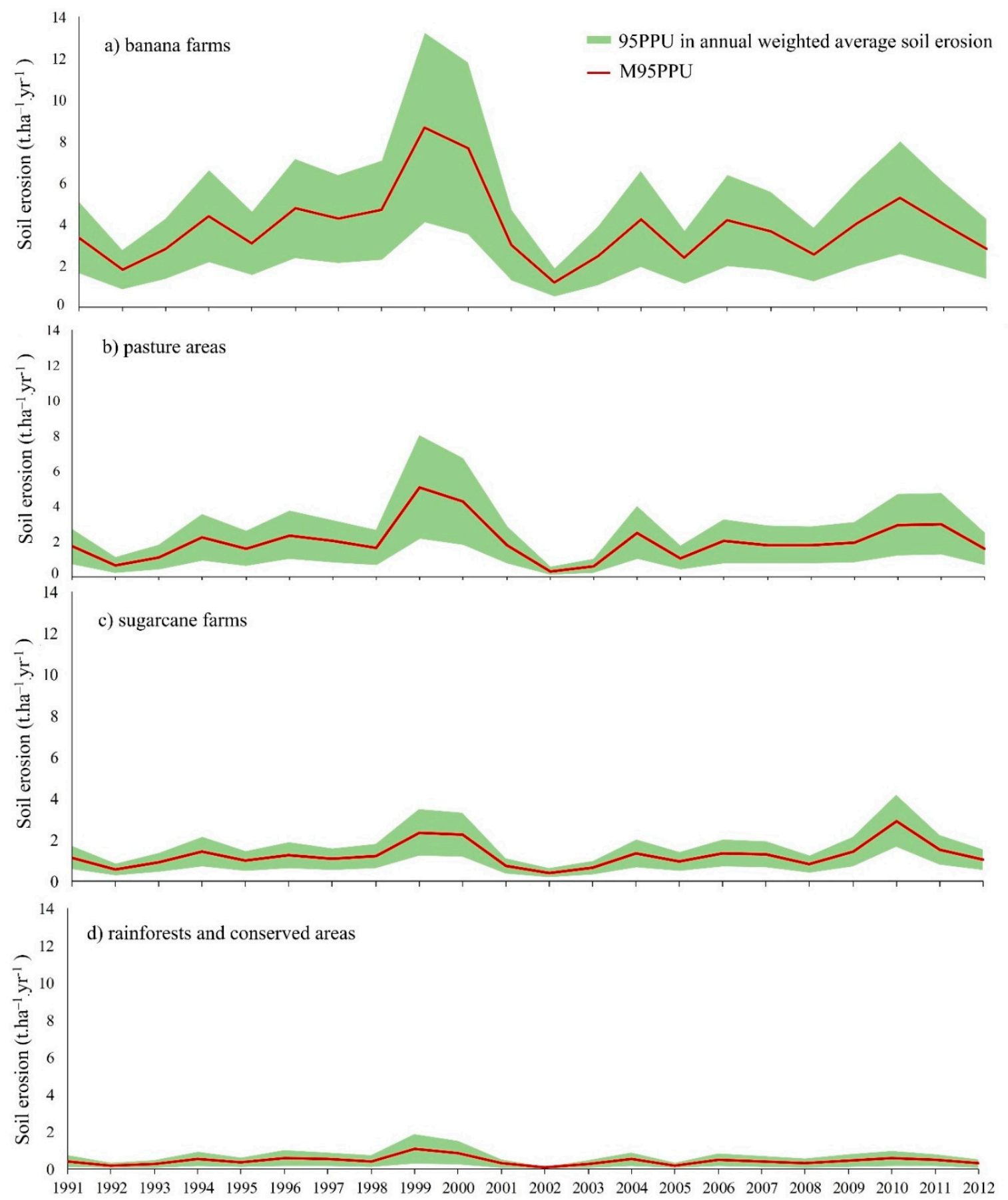

Figure 10. The 95PPU and average of 95PPU (M95PPU) of soil erosion in (a) banana farms, (b) pasture HRUs, (c) sugarcane HRUs, and (d) rainforests HRUs where 95PPU here represents the annual weighted average of soil erosion among the HRUs with the same land use based on their total land use area.

Table 5 shows the 95PPU of soil erosion rates among HRUs for the whole simulation period (1991-2012), classified based on slope range and land use. The median and mean of soil erosion rate are also included to show the tendency of simulated annual soil erosion rates. Accordingly, for a similar slope range, soil erosion rates in banana and sugarcane HRUs are about 1.5-2 times more than those of pasture HRUs and 10-12 times more than soil erosion in rainforests. For example, the 95PPU of soil erosion rates in pasture HRUs with less than $10 \%$ slope is between 0.03 and $2.73 \mathrm{t} \cdot \mathrm{ha}^{-1} \cdot \mathrm{year}^{-1}$ while the soil erosion for sugarcane and banana HRUs ranges from 0.19 to $5.63 \mathrm{t} \cdot \mathrm{ha}^{-1} \cdot \mathrm{year}^{-1}$ and 0.13 to $6.27 \mathrm{t} \cdot \mathrm{ha}^{-1} \cdot$ year $^{-1}$ respectively. 
Table 5. The 95PPU, median and mean of soil erosion rate $\left(\mathrm{t} \cdot \mathrm{ha}^{-1} \cdot \mathrm{year}^{-1}\right)$ in major land uses for the simulation period (1991-2012) classified based on slope range.

\begin{tabular}{|c|c|c|c|c|c|}
\hline \multirow{2}{*}{ Slope } & Area (ha) & Lower $(2.5 \%)$ & Upper (97.5\%) & Median & Mean \\
\hline & \multicolumn{5}{|c|}{ Forests } \\
\hline $0-10 \%$ & 10,105 & 0.001 & 0.52 & 0.02 & 0.08 \\
\hline $10-20 \%$ & 8182 & 0.001 & 1.44 & 0.04 & 0.21 \\
\hline $20-30 \%$ & 2391 & 0.002 & 2.56 & 0.10 & 0.39 \\
\hline $30-40 \%$ & 6074 & 0.001 & 3.42 & 0.07 & 0.46 \\
\hline $40-50 \%$ & 8444 & 0.002 & 5.51 & 0.11 & 0.83 \\
\hline $50-60 \%$ & 1518 & 0.004 & 6.65 & 0.15 & 0.83 \\
\hline $60-70 \%$ & 72 & 0.009 & 14.17 & 1.52 & 3.44 \\
\hline \multicolumn{6}{|c|}{ Pasture } \\
\hline $0-10 \%$ & 33,763 & 0.027 & 2.73 & 0.58 & 0.78 \\
\hline $10-20 \%$ & 12,382 & 0.108 & 8.63 & 1.64 & 2.36 \\
\hline $20-30 \%$ & 5270 & 0.141 & 14.66 & 2.73 & 3.96 \\
\hline $30-40 \%$ & 4043 & 0.125 & 20.72 & 3.71 & 5.43 \\
\hline $40-50 \%$ & 29 & 0.381 & 48.94 & 9.85 & 14.50 \\
\hline \multicolumn{6}{|c|}{ Banana } \\
\hline $0-10 \%$ & 2291 & 0.134 & 6.27 & 1.19 & 1.96 \\
\hline $10-20 \%$ & 256 & 1.052 & 16.15 & 5.53 & 6.89 \\
\hline $20-30 \%$ & 59 & 1.888 & 27.13 & 9.67 & 12.24 \\
\hline $30-40 \%$ & 11 & 3.873 & 28.90 & 12.63 & 14.07 \\
\hline \multicolumn{6}{|c|}{ Sugarcane } \\
\hline $0-10 \%$ & 3444 & 0.185 & 5.63 & 1.03 & 1.70 \\
\hline $10-20 \%$ & 76 & 2.050 & 14.36 & 5.96 & 6.80 \\
\hline $20-30 \%$ & 13 & 3.093 & 20.00 & 8.53 & 9.67 \\
\hline
\end{tabular}

It should be noted that the highest proportion of pasture areas is located in the upper section where precipitation is half of the average of the catchment and surface runoff is relatively less than in the coastal zone where sugarcane and bananas are located (Figure $8 \mathrm{~b}$ ). The lower amount of rainfall/runoff plus the lower range of USLE_C values for the pasture HRUs are the main reasons behind less simulated soil erosion rate in pasture HRUs with the same slope range compared to sugarcane and bananas HRUs. However, when considering the annual weighted average of soil erosion rates among land uses (accounting for the effect of slope steepness), the annual weighted average of simulated soil erosion in banana and pasture HRUs is higher than in sugarcane HRUs, as $12 \%$ of banana HRUs and 39\% of pasture HRUs are located on slope ranges of more than $10 \%$, while this value is only $3 \%$ for sugarcane HRUs. The highest soil erosion for all land uses occurred in 1999-the most extreme wet year-that the mean of the annual weighted average (M95PPU) for bananas HRUs was $8.2 \mathrm{t} \cdot \mathrm{ha}^{-1} \cdot \mathrm{year}^{-1}$, for pasture HRUs was $4.65 \mathrm{t}^{-} \cdot \mathrm{ha}^{-1} \cdot \mathrm{year}^{-1}$, for sugarcane HRUs was $2.12 \mathrm{t} \cdot \mathrm{ha}^{-1} \cdot \mathrm{year}^{-1}$ and for rainforest HRUs was $0.96 \mathrm{t}^{\mathrm{h}} \mathrm{ha}^{-1} \cdot$ year $^{-1}$. Moreover, the lowest soil erosion occurred in 2002 where the values of M95PPU for all land uses are less than $1 \mathrm{t} \cdot \mathrm{ha}^{-1} \cdot \mathrm{year}^{-1}$.

Figure 11 depicts the spatial maps of soil erosion under the extreme dry year (2002), the average of the simulation period (1991-2012) (Figure 11b), and the extreme wet year (1999) (Figure 11c). Average annual soil erosion rate for the catchment in the extreme dry year is $0.44 \mathrm{t} \cdot \mathrm{ha}^{-1} \cdot \mathrm{year}^{-1}$, while the average for the simulation period is $1.88 \mathrm{t} \cdot \mathrm{ha}^{-1} \cdot \mathrm{year}^{-1}$ and for the extreme wet year is $4.32 \mathrm{t} \cdot \mathrm{ha}^{-1} \cdot \mathrm{year}^{-1}$. The standard deviation of soil erosion rates for all land uses for the extreme dry year is 0.96 , for the average of simulation period is 3.20 and for the extreme wet year is 7.34. The 97.5 percentile of soil erosion among all land uses for the extreme dry year is 0.96 , for average of the simulation period is $9.88 \mathrm{t} \cdot \mathrm{ha}^{-1} \cdot \mathrm{year}^{-1}$ and for the extreme wet year is $20.75 \mathrm{t} \cdot \mathrm{ha}^{-1} \cdot \mathrm{year}^{-1}$. The coastal zone and the upper section of the catchment, dominated by sugarcane, bananas and pasture HRUs, are sensitive to rainfall, 
while the middle section of the catchment, dominated by rainforests, seldom changes with fluctuations in rainfall as they generate relatively low surface runoff as shown in Figure 8b.

a)

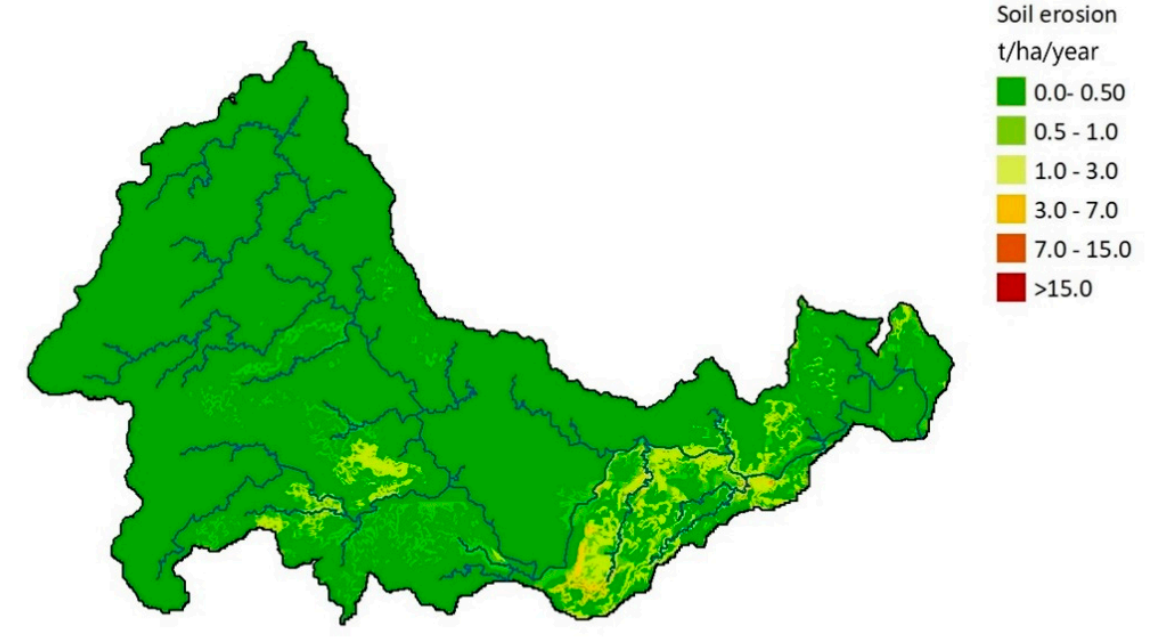

b)

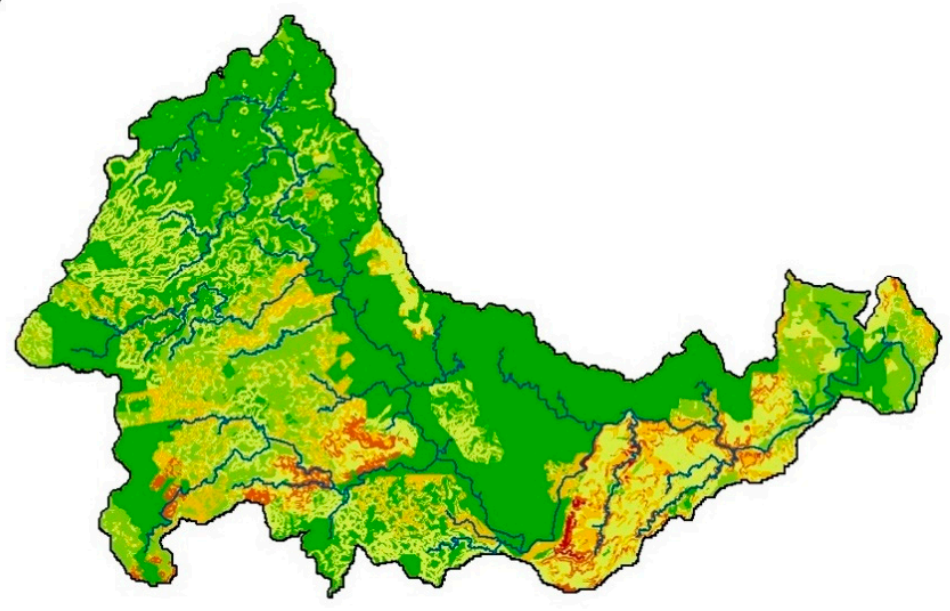

c)

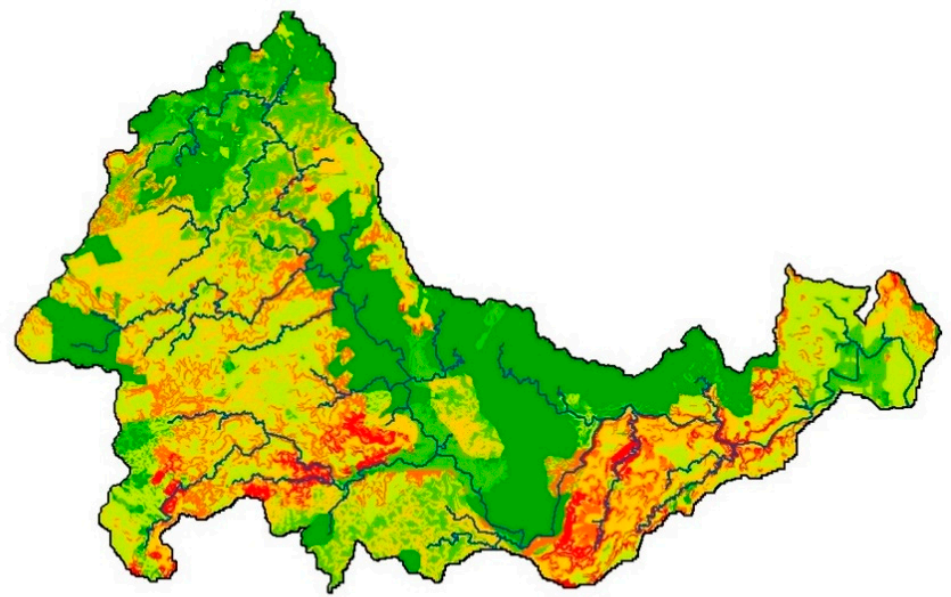

Figure 11. Spatial maps of (a) average simulated soil erosion for the extreme dry year (2002), (b) average simulated soil erosion of the simulation period (1991-2002), and (c) average simulated soil erosion for the extreme wet year (1999). 


\section{Discussion}

\subsection{Comparison Soil Erosion with Previous Studies}

In previous modelling efforts, the sediment and soil erosion for this catchment has been estimated, however, we designed this research to further investigate the details of water balance components, the impact of slope steepness and spatio-temporal variations on soil erosion across the North Johnstone catchment. The SWAT simulated streamflow rate, $\mathrm{ET}_{\mathrm{a}}$ and sediment loads were in reasonable agreement with observed values and the predictive uncertainty of model simulations could capture most of the observation with an acceptable error band thickness. This indicates that the model provided a good representation of catchment hydrology and soil erosion.

Our modelling results were also in agreement with Hunter and Walton [13] that used the Hydrological Simulation Program-FORTRAN (HSPF) model to simulate constituent loads including sediment fluxes from North and South Johnstone to GBR. The authors estimated sediment fluxes from banana $\left(4.0 \pm 2.5 \mathrm{t} \cdot \mathrm{ha}^{-1} \cdot\right.$ year $\left.^{-1}\right)$, sugarcane $\left(3.8 \pm 2.5 \mathrm{t} \cdot \mathrm{ha}^{-1} \cdot \mathrm{year}^{-1}\right)$, rainforests and pasture areas $\left(1.2 \pm 1.1 \mathrm{t} \cdot \mathrm{ha}^{-1} \cdot\right.$ year $\left.^{-1}\right)$. However, although we found a similar level of soil erosion in banana and sugarcane farms within the same slope range (Table 5), when taking into account the effect of slope steepness, we found that annual weighted average of soil erosion among banana and pasture HRUs is higher than in sugarcane HRUs as only 3\% of sugarcane areas have slope range more than $10 \%$, while this value is $12 \%$ for banana land use and $39 \%$ for pasture land use.

\subsection{Hillslope Soil Erosion Modelling for GBR Catchments}

The $R_{U S L E}$ model which is a derivative version of the USLE model with some improvement in erosion controlling factors has been widely used for estimating hillslope soil erosion for Australian catchments. However, continuous research showed that $R_{U S L E}$ generally overestimates soil erosion, especially for steep rainforest areas [14,57]. To resolve this overestimation, in current modelling sediment loads for GBR by the Reef Water Quality Protection Plan, the $R_{U S L E}$ model is only being applied for grazing land use and the Event Mean Concentration/Dry Weather Concentration (EMC/DWC) model being used for modelling erosion in rainforests and banana farms [17]. However, EMC/DWC cannot account for hillslope erosion and further improvement is required [17]. A clear example for overestimation of $R_{U S L E}$ is Teng et al. [58] who used the $R_{U S L E}$ to estimate soil erosion for the Australian continent. Teng et al. [58] reported that based on their modelling results, the Johnstone catchment has large rates of soil erosion and predicted more than $50 \mathrm{t} \cdot \mathrm{ha}^{-1} \cdot \mathrm{year}^{-1}$ soil erosion for the rainforest dominated area in the middle section of the catchment. In a notable contrast, the SWAT model which uses the $M_{U S L E}$ model and replaces the rainfall erosivity factor in $R_{U S L E}$ by the runoff factor, predicted more accurately a significantly lower amount of soil erosion for the rainforest dominated area. Furthermore, our soil erosion results for banana land use can be directly compared with a recent paddock scale sediment monitoring in the Johnstone catchment [59] which showed during the water year of 2010-2011 that the farm received more than $5000 \mathrm{~mm}$ rainfall, and the soil erosion (the farm had no management practices such grassed inter row) was around $11 \mathrm{t} \cdot \mathrm{ha}^{-1} \cdot \mathrm{year}^{-1}$. Our modelling results also show that in an extreme wet year with more than $5000 \mathrm{~mm}$ rainfall, the weighted average of soil erosion for banana HRUs can be as low as $3 \mathrm{t} \cdot \mathrm{ha}^{-1} \cdot \mathrm{year}^{-1}$ and as high as $13 \mathrm{t} \cdot \mathrm{ha}^{-1} \cdot \mathrm{year}^{-1}$. However, although using $M_{U S L E}$ could more accurately predict soil erosion, this approach required a sophisticated and computationally extensive calibration and validation for both hydrology and sediment load.

\subsection{The Effectiveness of Reforestation on Steep Slopes}

The hypothesis that reforestation can reduce sediment is examined here by using a set of scenarios and with the assistance of the SWAT model validated for this region. For this purpose, we designed four land-use change scenarios from pasture to rainforests based on four slope groups for a six-year period (Figure 12). As reforestation is not an instantaneous process, we considered that reforestation in 
designated pasture areas initiated in 1991 and restored forests reached full maturity in 2007. Hence, for the first scenario, we converted all pasture land uses with more than $30 \%$ slope ( $4071 \mathrm{ha}$ ) to rainforests. The results show that changing land use in these steep slope areas to rainforests reduced $15 \%$ sediment loads within six years which is equal to 25,000 tonnes per year. In the second scenario, pasture areas with more than 20\% slope (9342 ha) are converted into rainforest which resulted in $26 \%$ reduction in sediment delivery to GBR (equal to 45,000 tonnes per year). In the third scenario, all pasture areas with more than $10 \%$ slope (21,724 ha) are converted into rainforests and resulted in a $40 \%$ reduction in sediment loads at the end of the catchment. Finally, converting all pasture areas to rainforest (55,487 ha) showed just a subtle difference from the third scenario ( $47 \%$ reduction in total sediment loads).
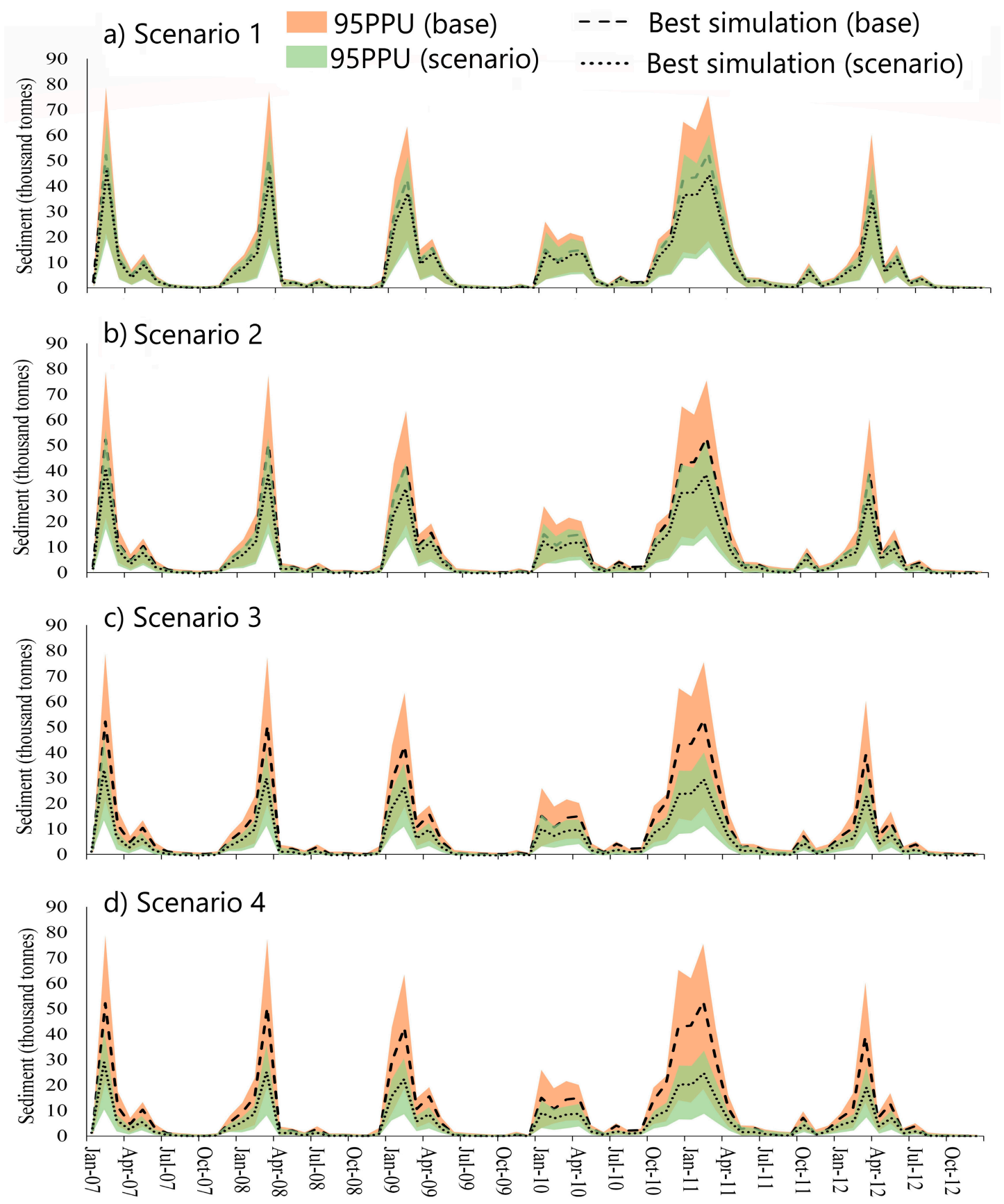

Figure 12. Monthly soil erosion affected under different land use scenarios: (a) pasture with slope more than $30 \%$ to forest, (b) pasture with a slope more than $20 \%$ to forest, (c) pasture with slope more than $10 \%$ to forest, (d) all pasture to forest (2007-2012). 
Overall, based on these modelling results, further management practices (e.g., reforestation and grassed inter row) for reducing soil erosion should be prioritised in high slope areas, specifically in pasture areas and banana farms. The identified sediment hotspots in this study can be considered for implanting further monitoring stations or used for carrying out soil erosion studies. Moreover, to reduce predictive uncertainty for simulating soil erosion from banana farms in the future modelling, a database that shows the spatial map of management practices can significantly improve the output.

\section{Conclusions}

In this research, we assessed hydrological processes and soil erosion and identified hotspots for management interventions in a tropical catchment of GBR. The SWAT model was applied to the North Johnstone catchment. The parameterisation of biophysical processes such as plant growth and ground cover were carried out using remote sensing database or field based studies. We calibrated and validated the model and quantified predictive uncertainty in simulating streamflow and sediment loads at the catchment and sub-catchment scale. The results were in reasonable agreement to observed values. For further analysis, the impact of slope steepness and spatio-temporal variations on soil erosion across the catchment were rigorously investigated. Finally, four land use change scenarios were applied to evaluate the effectiveness of converting pasture areas to rainforests in reducing sediment fluxes to GBR. Our results show that converting pasture areas with slopes more than $30 \%$ and $20 \%$ which cover $4 \%$ and $9 \%$ of the catchment, can potentially reduce $15 \%$ and $26 \%$ of the annual sediment loads to GBR.

Author Contributions: Conceptualization, V.R. and A.G.; methodology, V.R. and A.G.; software, V.R.; validation, V.R., A.G. and D.-A.A.-V.; formal analysis, V.R.; investigation, V.R.; resources, S.M. and D.-A.A.-V.; data curation, V.R. and A.G.; writing—original draft preparation, V.R.; writing—-review and editing, D.-A.A.-V., A.G. and S.M.; visualization, V.R.; supervision, S.M., A.G. and D.-A.A.-V.; project administration, S.M. All authors have read and agreed to the published version of the manuscript.

Funding: This research received no external funding.

Acknowledgments: We acknowledge the University of Southern Queensland for providing an international fees research scholarship to the first author. We thank the State of Queensland (Department of Environment and Science) for providing monitoring data. The authors also acknowledge the helpful proofreading work from Barbara Harmes and reviewers for providing valuable comments, which improved this manuscript.

Conflicts of Interest: The authors declare no conflicts of interest.

\section{References}

1. Griggs, P.D. Too much water: Drainage schemes and landscape change in the sugar-producing areas of Queensland, 1920-1990. Aust. Geogr. 2018, 49, 81-105. [CrossRef]

2. Evans, M.C. Deforestation in Australia: Drivers, trends and policy responses. Pac. Conserv. Biol. 2016, 22, 130-150. [CrossRef]

3. Rasiah, V.; Florentine, S.K.; Williams, B.L.; Westbrooke, M.E. The impact of deforestation and pasture abandonment on soil properties in the wet tropics of Australia. Geoderma 2004, 120, 35-45. [CrossRef]

4. Bradshaw, C.J. Little left to lose: Deforestation and forest degradation in Australia since European colonization. Plant Ecol. 2012, 5, 109-120. [CrossRef]

5. Kroon, F.J. Towards ecologically relevant targets for river pollutant loads to the Great Barrier Reef. Mar. Pollut. Bull. 2012, 65, 261-266. [CrossRef]

6. Waterhouse, J.; Brodie, J.; Tracey, D.; Smith, R.; Vandergragt, M.; Collier, C.; Petus, C.; Baird, M.; Kroon, F.; Mann, R.; et al. The Risk from Anthropogenic Pollutants to Great Barrier Reef Coastal and Marine Ecosystems. In Scientific Consensus Statement 2017: A Synthesis of the Science of Land-Based Water Quality Impacts on the Great Barrier Reef; Queensland Department of Environment and Science: Brisbane, Australia, 2017. Available online: https://www.reefplan.qld.gov.au/_data/assets/pdf_file/0032/45995/2017-scientificconsensus-statement-summary-chap03.pdf (accessed on 1 August 2020). 
7. Waterhouse, J.; Schaffelke, B.; Bartley, R.; Eberhard, R.; Brodie, J.; Star, M.; Thorburn, P.; Rolfe, J.; Ronan, M.; Taylor, B.; et al. Overview of Key Findings, Management Implications and Knowledge Gaps. In 2017 Scientific Consensus Statement: Land Use Impacts on the Great Barrier Reef Water Quality and Ecosystem Condition; Queensland Department of Environment and Science: Brisbane, Australia, 2017. Available online: https://www.reefplan.qld.gov.au/_data/assets/pdf_file/0034/45997/2017-scientificconsensus-statement-summary-chap05.pdf (accessed on 1 August 2020).

8. Bartley, R.; Thompson, C.; Croke, J.; Pietsch, T.; Baker, B.; Hughes, K.; Kinsey-Henderson, A. Insights into the history and timing of post-European land use disturbance on sedimentation rates in catchments draining to the Great Barrier Reef. Mar. Pollut. Bull. 2018, 131, 530-546. [CrossRef] [PubMed]

9. Hairsine, P.B. Sediment-Related Controls on the Health of the Great Barrier Reef. Vadose Zone J. 2017, 16, 1-15. [CrossRef]

10. Ebner, B.C.; Fulton, C.J.; Donaldson, J.A.; Schaffer, J. Distinct habitat selection by freshwater morays in tropical rainforest streams. Ecol. Freshw. Fish. 2016, 25, 329-335. [CrossRef]

11. Wilkinson, S.N.; Dougall, C.; Kinsey-Henderson, A.E.; Searle, R.D.; Ellis, R.J.; Bartley, R. Development of a time-stepping sediment budget model for assessing land use impacts in large river basins. Sci. Total Environ. 2014, 468, 1210-1224. [CrossRef] [PubMed]

12. Herr, A.; Kuhnert, P.M. Assessment of uncertainty in Great Barrier Reef catchment models. Water Sci. Technol. 2007, 56, 181-188. [CrossRef] [PubMed]

13. Hunter, H.M.; Walton, R.S. Land-use effects on fluxes of suspended sediment, nitrogen and phosphorus from a river catchment of the Great Barrier Reef, Australia. J. Hydrol. 2008, 356, 131-146. [CrossRef]

14. Armour, J.D.; Hateley, L.R.; Pitt, G.L. Catchment modelling of sediment, nitrogen and phosphorus nutrient loads with SedNet/ANNEX in the Tully-Murray basin. Mar. Freshw. Res. 2009, 60, 1091-1096. [CrossRef]

15. Gladish, D.W.; Kuhnert, P.M.; Pagendam, D.E.; Wikle, C.K.; Bartley, R.; Searle, R.D.; Ellis, R.J.; Dougall, C.; Turner, R.D.; Lewis, S.E.; et al. Spatio-temporal assimilation of modelled catchment loads with monitoring data in the Great Barrier Reef. Ann. Appl. Stat. 2016, 10, 1590-1618. [CrossRef]

16. Hughes, A.O.; Croke, J.C. Validation of a spatially distributed erosion and sediment yield model (SedNet) with empirically derived data from a catchment adjacent to the Great Barrier Reef Lagoon. Mar. Freshw. Res. 2011, 62, 962-973. [CrossRef]

17. Hateley, L.R.; Ellis, R.; Shaw, M.; Waters, D.; Carroll, C. Modelling Reductions of Pollutant Loads Due to Improved Management Practices in the Great Barrier Reef Catchments-Wet Tropics NRM Region; Technical Report; Queensland Department of Natural Resources and Mines: Cairns, Australia, 2014; Volume 3, ISBN 978-0-7345-0441-8.

18. An-Vo, D.A.; Mushtaq, S.; Reardon-Smith, K.; Kouadio, L.; Attard, S.; Cobon, D.; Stone, R. Value of seasonal forecasting for sugarcane farm irrigation planning. Eur. J. Agron. 2019, 104, 37-48. [CrossRef]

19. An-Vo, D.A.; Reardon-Smith, K.; Mushtaq, S.; Cobon, D.; Kodur, S.; Stone, R. Value of seasonal climate forecasts in reducing economic losses for grazing enterprises: Charters Towers case study. Rangel. J. 2019, 41, 165-175. [CrossRef]

20. Henderson, B.; Bui, E. Determining Uncertainty in Sediment \& Nutrient Transport Models for Ecological Risk Assessment (No. 2); CSIRO: Canberra, Australia, 2005.

21. Fu, B.; Merritt, W.S.; Croke, B.F.; Weber, T.; Jakeman, A.J. A review of catchment-scale water quality and erosion models and a synthesis of future prospects. Environ. Model. Softw. 2019, 114, 75-97. [CrossRef]

22. Neitsch, S.L.; Arnold, J.G.; Kiniry, J.R.; Williams, J.R. Soil and Water Assessment Tool Theoretical Documentation Version 2009; Texas Water Resources Institute: College Station, TX, USA, 2011.

23. Abbaspour, K.C. SWAT-CUP4: SWAT Calibration and Uncertainty Programs-A User Manual; Swiss Federal Institute of Aquatic Science and Technology, Eawag: Überland, Switzerland, 2011.

24. Bartley, R.; Waters, D.; Turner, R.; Kroon, F.; Wilkinson, S.; Garzon-Garcia, A.; Kuhnert, P.; Lewis, S.; Smith, R.; Bainbridge, Z.; et al. Sources of Sediment, Nutrients, Pesticides and other Pollutants to the Great Barrier Reef. In Scientific Consensus Statement 2017: A Synthesis of the Science of Land-Based Water Quality Impacts on the Great Barrier Reef; Queensland Department of Environment and Science: Brisbane, Australia, 2017. Available online: https://www.reefplan.qld.gov.au/_data/assets/pdf_file/0031/45994/2017-scientificconsensus-statement-summary-chap02.pdf (accessed on 1 August 2020).

25. Wilkinson, C.; Brodie, J. Catchment Management and Coral Reef Conservation; James Cock University: Douglas, Australia, 2011. 
26. Marden, M. Effectiveness of reforestation in erosion mitigation and implications for future sediment yields, East Coast catchments, New Zealand: A review. N. Z. Geog. 2012, 68, 24-35. [CrossRef]

27. Delevaux, J.M.; Whittier, R.; Stamoulis, K.A.; Bremer, L.L.; Jupiter, S.; Friedlander, A.M.; Poti, M.; Guannel, G.; Kurashima, N.; Winter, K.B.; et al. A linked land-sea modeling framework to inform ridge-to-reef management in high oceanic islands. PLoS ONE 2018, 13, e0193230. [CrossRef]

28. Faruqi, S.; Wu, A.; Brolis, E.; Ortega, A.A.; Batista, A. The Business of Planting Trees: A Growing Investment Opportunity; World Resources Institute: Washington, DC, USA, 2018.

29. Carlson, R.R.; Foo, S.A.; Asner, G.P. Land use impacts on coral reef health: A ridge-to-reef perspective. Front. Mar. Sci. 2019, 6, 562. [CrossRef]

30. Preece, N.D.; Van Oosterzee, P.; Lawes, M.J. Planting methods matter for cost-effective rainforest restoration. Ecol. Manag. Restor. 2013, 14, 63-66. [CrossRef]

31. Cheesman, A.W.; Preece, N.D.; van Oosterzee, P.; Erskine, P.D.; Cernusak, L.A. The role of topography and plant functional traits in determining tropical reforestation success. J. Appl. Ecol. 2018, 55, 1029-1039. [CrossRef]

32. Ndomba, P.; Mtalo, F.; Killingtveit, A. SWAT model application in a data scarce tropical complex catchment in Tanzania. Phys. Chem. Earth 2008, 33, 626-632. [CrossRef]

33. Alansi, A.W.; Amin, M.S.M.; Halim, F.A.; Shafri, H.Z.M.; Aimrum, W. Validation of SWAT model for stream flow simulation and forecasting in Upper Bernam humid tropical river basin, Malaysia. Hydrol. Earth. Syst. Sci. Discuss. 2009, 1, 6. [CrossRef]

34. Fukunaga, D.C.; Cecílio, R.A.; Zanetti, S.S.; Oliveira, L.T.; Caiado, M.A.C. Application of the SWAT hydrologic model to a tropical watershed at Brazil. Catena 2015, 125, 206-213. [CrossRef]

35. Williams, J.R.; LaSeur, W.V. Water yield model using SCS curve numbers. J. Hydr. Eng. DIV 1976, $102,12379$.

36. Monteith, J.L. Evaporation and environment. In Symposia of the Society for Experimental Biology; Cambridge University Press: Cambridge, UK, 1965; pp. 205-234.

37. Hargreaves, G.L.; Hargreaves, G.H.; Riley, J.P. Irrigation water requirements for Senegal River basin. J. Irrig. Drain. E-ASCE 1985, 111, 265-275. [CrossRef]

38. Priestley, C.H.B.; Taylor, R.J. On the assessment of surface heat flux and evaporation using large-scale parameters. Mon. Weather Rev. 1972, 100, 81-92. [CrossRef]

39. Willams, J.R. Sediment-yield prediction with universal equation using runoff energy factor. In Present and Prospective Technology for Predicting Sediment Yields and Sources; US Department of Agriculture, Agriculture Research Service: Washington, DC, USA, 1975.

40. Williams, J.R.; Berndt, H.D. Sediment yield prediction based on watershed hydrology. Trans. ASAE 1977, 20, 1100-1104. [CrossRef]

41. Bagnold, R.A. Bed load transport by natural rivers. Water Resour. Res. 1977, 13, 303-312. [CrossRef]

42. Bureau of Agricultural and Resource Economics and Sciences. The Australian Land Use and Management Classification Version 8; Bureau of Agricultural and Resource Economics and Sciences: Canberra, Australia, 2016.

43. McKenzie, N.J.; Jacquier, D.W.; Maschmedt, D.J.; Griffin, E.A.; Brough, D.M. The Australian Soil Resource Information System (ASRIS) Technical Specifications, Revised Version 1.6; CSIRO: Canberra, Australia, 2012.

44. Walling, D.E.; WEBB, B.W. The Reliability of Suspended Sediment Load Data. In Erosion and Sediment Transport Measurement, Proceedings of the Florence Symposium, Firenze, Italy, 22-26 June 1981; Volume 133, pp. 177-194. Available online: https://iahs.info/uploads/dms/iahs_133_0177.pdf (accessed on 1 August 2020).

45. Frost, A.J.; Ramchurn, A.; Smith, A. The Australian Landscape Water Balance Model. (AWRA-L v6). Technical Description of the Australian Water Resources Assessment Landscape Model. Version 6; Bureau of Meteorology Technical Report: Melbourne, Australia, 2018.

46. Daggupati, P.; Pai, N.; Ale, S.; Douglas-Mankin, K.R.; Zeckoski, R.W.; Jeong, J.; Parajuli, P.B.; Saraswat, D.; Youssef, M.A. A recommended calibration and validation strategy for hydrologic and water quality models. Trans. ASABE 2015, 58, 1705-1719.

47. Baez-Gonzalez, A.D.; Kiniry, J.R.; Meki, M.N.; Williams, J.; Alvarez-Cilva, M.; Ramos-Gonzalez, J.L.; Magallanes-Estala, A.; Zapata-Buenfil, G. Crop parameters for modeling sugarcane under rainfed conditions in Mexico. Sustainability 2017, 9, 1337. [CrossRef] 
48. Robertson, M.J.; Bonnett, G.D.; Hughes, R.M.; Muchow, R.C.; Campbell, J.A. Temperature and leaf area expansion of sugarcane: Integration of controlled-environment, field and model studies. Funct. Plant. Biol. 1998, 25, 819-828. [CrossRef]

49. Keating, B.A.; Robertson, M.J.; Muchow, R.C.; Huth, N.I. Modelling sugarcane production systems I. Development and performance of the sugarcane module. Field Crops. Res. 1999, 61, 253-271. [CrossRef]

50. Guimarães, M.J.M.; Coelho Filho, M.A.; Peixoto, C.P.; Gomes Junior, F.D.A.G.; Oliveira, V.V.M. Estimation of leaf area index of banana orchards using the method LAI-LUX. Water Resour. Irrig. Manag. 2013, 2, 71-76.

51. Gilmour, D.A. Catchment Water Balance Studies on the Wet Tropical Coast of North Queensland. Ph.D. Thesis, James Cook University, Townsville, Australia, 1975.

52. Moriasi, D.N.; Zeckoski, R.W.; Arnold, J.G.; Baffaut, C.; Malone, R.W.; Daggupati, P.; Guzman, J.A.; Saraswat, D.; Yuan, Y.; Wilson, B.N.; et al. Hydrologic and water quality models: Key calibration and validation topics. Trans. ASABE 2015, 58, 1609-1618.

53. Abbaspour, K.C.; Johnson, C.A.; Van Genuchten, M.T. Estimating uncertain flow and transport parameters using a sequential uncertainty fitting procedure. Vadose Zone J. 2004, 3, 1340-1352. [CrossRef]

54. McKay, M.D.; Beckman, R.J.; Conover, W.J. Comparison of three methods for selecting values of input variables in the analysis of output from a computer code. Technometrics 1979, 21, 239-245.

55. Abbaspour, K.C.; Vaghefi, S.A.; Srinivasan, R. A guideline for successful calibration and uncertainty analysis for soil and water assessment: A review of papers from the 2016 International SWAT Conference. Water 2018, 10, 6. [CrossRef]

56. Arnold, J.G.; Allen, P.M. Automated methods for estimating baseflow and ground water recharge from streamflow records 1. J. Am. Water. Resour. Assoc. 1999, 35, 411-424. [CrossRef]

57. Brooks, A.; Spencer, J.; Borombovits, D.; Pietsch, T.; Olley, J. Measured hillslope erosion rates in the wet-dry tropics of Cape York, northern Australia: Part 2, RUSLE-based modeling significantly over-predicts hillslope sediment production. Catena 2014, 122, 1-17. [CrossRef]

58. Teng, H.; Rossel, R.A.V.; Shi, Z.; Behrens, T.; Chappell, A.; Bui, E. Assimilating satellite imagery and visible-near infrared spectroscopy to model and map soil loss by water erosion in Australia. Environ. Model. Softw. 2016, 77, 156-167. [CrossRef]

59. Armour, J.D.; Davis, A.; Masters, B.; Mortimore, C.; Whitten, M. Paddock Scale Water Quality Monitoring of Sugarcane and Banana Management Practices: Final Technical Report 2010-2013 Wet Seasons; Wet Tropics Region, Queensland Department of Natural Resources and Mines, Centre for Tropical Water \& Aquatic Ecosystem Research and Queensland Department of Agriculture, Fisheries and Forestry for Terrain Natural Resource Management: Mareeba, Australia, 2013. 